\title{
Effect of Water Vapor on High-Temperature Corrosion under Conditions Mimicking Biomass Firing
}

Okoro, Sunday Chukwudi; Montgomery, Melanie; Jappe Frandsen, Flemming; Pantleon, Karen

\section{Published in:}

Energy \& Fuels

Link to article, DOI:

10.1021/acs.energyfuels.5b01045

Publication date:

2015

Document Version

Peer reviewed version

Link back to DTU Orbit

Citation (APA):

Okoro, S. C., Montgomery, M., Jappe Frandsen, F., \& Pantleon, K. (2015). Effect of Water Vapor on HighTemperature Corrosion under Conditions Mimicking Biomass Firing. Energy \& Fuels, 29(9), 5802-5815. https://doi.org/10.1021/acs.energyfuels.5b01045

\section{General rights}

Copyright and moral rights for the publications made accessible in the public portal are retained by the authors and/or other copyright owners and it is a condition of accessing publications that users recognise and abide by the legal requirements associated with these rights.

- Users may download and print one copy of any publication from the public portal for the purpose of private study or research.

- You may not further distribute the material or use it for any profit-making activity or commercial gain

- You may freely distribute the URL identifying the publication in the public portal 


\title{
The effect of water vapour on high temperature corrosion under conditions mimicking biomass-firing
}

\author{
Sunday Chukwudi Okoro ${ }^{1, *}$, Melanie Montgomery ${ }^{1}$, Flemming Jappe Frandsen ${ }^{2}$, Karen Pantleon ${ }^{1}$ \\ ${ }^{1}$ Technical University of Denmark (DTU), Department of Mechanical Engineering, 2800 Kongens \\ Lyngby, Denmark.
}

${ }^{2}$ DTU, CHEC Research Centre, Department of Chemical and Biochemical Engineering, 2800 Kongens Lyngby, Denmark.

KEYWORDS. High temperature corrosion, $\mathrm{KCl}$, sulphation, $\mathrm{H}_{2} \mathrm{O}$ vapour, austenitic stainless steel.

\begin{abstract}
The variable flue gas composition in biomass-fired plants, among other parameters, contributes to the complexity of high temperature corrosion of materials. Systematic parameter studies are thus necessary to understand the underlying corrosion mechanisms. This paper investigates the effect of water $\left(\mathrm{H}_{2} \mathrm{O}\right)$ vapour content in the flue gas, on the high temperature corrosion of austenitic stainless steel (TP 347H FG) under laboratory conditions, to improve the understanding of corrosion mechanisms. Deposit-coated and deposit-free samples were isothermally exposed for $72 \mathrm{~h}$ in a synthetic flue gas atmosphere containing either 3 vol \% or 13 vol $\% \mathrm{H}_{2} \mathrm{O}$ vapour. Comprehensive characterization of the corrosion products was carried out by the complementary use of microscopic, spectroscopic and diffraction based techniques. To evaluate the effect of the exposure time, results were compared to previous results with longer isothermal exposure over $168 \mathrm{~h}$, and indicated that the development of a Nirich layer due to selective attack was time dependent. The increase in water vapour decreased the measurable corrosion attack, and, in addition decreased sulphation was observed. Results from the current investigation and from previously reported findings suggest that an increase in water vapour will cause competitive adsorption on active sites.
\end{abstract}

\section{Introduction}

One of the major operational challenges experienced in power plants firing biomass is the severe corrosion of superheater tubes [1-4]. The release of $\mathrm{K}, \mathrm{Cl}, \mathrm{S}$ and other organically/inorganically associated species into the vapour phase during combustion of biomass leads to subsequent condensation of deposits on superheater tubes [5]. The corrosion rate caused by $\mathrm{KCl}$ containing deposits accelerates with increasing steam temperatures, and therefore reduces the efficiency of biomass-fired plants relative 
to those fired with fossil fuels. As a consequence, the outlet steam temperature of biomass fired plants (in Denmark) is limited to about $540{ }^{\circ} \mathrm{C}$.

$\mathrm{KCl}$ induced corrosion of high temperature materials has been the subject of a number of investigations [6-13] to clarify the mechanism of attack in order to pave the way for the development of advanced high temperature resistant materials. Laboratory investigations have shown that the alkali earth metal plays a role in the initial corrosion process [8,10,14-17]. Such studies indicate that a protective $\mathrm{Cr}_{2} \mathrm{O}_{3}$ layer cannot be formed on high Cr-alloyed steels due to the formation of $\mathrm{K}_{2} \mathrm{CrO}_{4}$ which leads to the formation of a Fe-rich porous oxide. Chlorine transport through the scale was suggested to proceed according to an electrochemical -“Wagner type" redox mechanism involving $\mathrm{Cl}$ reduction and metal oxidation $[16,18]$.

However, other studies with $\mathrm{SO}_{2}$ in the gas reported that corrosion is accelerated by $\mathrm{Cl}$ generation from the sulphation of the alkali chloride present in the deposit $[13,19,20]$. In such studies, it was suggested that the $\mathrm{HCl}$ released from sulphation of the deposits is able to dissociate according to the Deacon reaction [21] into $\mathrm{Cl}$ species which are transported through cracks and pores to the corrosion front. A cyclic attack involving the chlorination, oxidation and re-chlorination by the released chlorine was proposed to be responsible for the increased corrosion attack $[13,19,20]$.

Other studies [11,22-27] suggest that $\mathrm{SO}_{2}$ in the flue gas can affect the corrosion process in a couple of ways:

(a) fast conversion of the corrosive chloride $(\mathrm{KCl})$ to the less corrosive sulphate $\left(\mathrm{K}_{2} \mathrm{SO}_{4}\right)[23,26]$. In this process, $\mathrm{SO}_{2}$ is also converted to $\mathrm{SO}_{3}$,

(b) formation of surface sulphates which prevent the vaporisation of $\mathrm{CrO}_{3}(\mathrm{OH})_{2}$ and thus, slow down the corrosion process [26,27], and;

(c) the ability of surface sulphates to inhibit surface reactions involved in corrosion [27].

It has to be noted however, that most of such studies have been carried out either with a very low surface coverage of the deposits on the samples, or with very high concentrations of $\mathrm{SO}_{2}$ which may affect the sulphation and, hence, the corrosion process. In fact, it was stated [23] that a high concentration of $\mathrm{SO}_{2}$ may induce preferential sulphation at the gas-deposit interface resulting in $\mathrm{HCl}$ generation away from the metal surface.

Effects of $\mathrm{H}_{2} \mathrm{O}$ vapour on high temperature corrosion of materials have been widely investigated in the absence of deposits (relevant to steamside oxidation of superheater tubes) [28-38]. Generally the corrosion results in an outward growing magnetite layer and an inward growing $\mathrm{Fe}-\mathrm{Cr}$ spinel phase. Likewise in the presence of synthetic deposits in simplified atmospheres (relevant to fireside corrosion during biomass-firing), the effect of $\mathrm{H}_{2} \mathrm{O}$ vapour has frequently been studied [10,34,39-43]. Results from 
such investigations revealed that $\mathrm{H}_{2} \mathrm{O}$ can exert either an accelerating [10,41-43] or inhibiting [34,39,40] effect on the corrosion of the investigated samples. Hence, a need for further understanding of its effect on the corrosion process is important. Even more indispensable is the need to investigate the effect of $\mathrm{H}_{2} \mathrm{O}$ vapour under realistic laboratory-scale conditions related to biomass-firing and its possible influence on the sulphation of the deposits.

This paper focuses on laboratory-scaled investigations of high temperature corrosion of an austenitic stainless steel (TP 347H FG) under conditions mimicking biomass-firing in thermal power plants. The effect of the amount of $\mathrm{H}_{2} \mathrm{O}$ vapour in the flue gas stream was investigated to gain better understanding of its influence on both the deposit sulphation and the corrosion mechanism. Results are compared to those from an exposure at $168 \mathrm{~h}$ [44] to reveal the influence of exposure time.

\section{Experimental procedures}

\subsection{Sample preparation}

Fine grained (FG) TP 347H austenitic stainless steel (chemical composition given in Table 1) was used for the present investigation. Arc shaped samples with a surface area of $1.2 \mathrm{~cm}^{2}$ of concave curvature were cut from a virgin steel tube utilised as superheater tubes in the plants. The samples were ultrasonically degreased in acetone and subsequently dried with ethanol. Afterwards, the concave surfaces of some of the clean samples were coated with a slurry of the synthetic deposit prepared by mixing $32-63 \mu \mathrm{m}$ sized $\mathrm{KCl}$ particles in a solution of 2-propanol. Each sample was coated with a $1 \mathrm{~mm}$ thick deposit. Using deposit slurries for laboratory investigation of high temperature corrosion forms part of the EU guidelines for effective simulation of such processes $[45,46]$.

Table 1. Chemical composition (in wt \%) of the as-received steel (TP 347H FG)

\begin{tabular}{llllll}
\hline $\mathrm{Si}$ & $\mathrm{Cr}$ & $\mathrm{Mn}$ & $\mathrm{Ni}$ & $\mathrm{Fe}$ & $\mathrm{Nb}$ \\
0.4 & 18.1 & 2.0 & 10.3 & 68.7 & 0.5 \\
\hline
\end{tabular}

\subsection{High temperature corrosion exposures}

High temperature exposure of both deposit-coated and deposit-free samples was carried out in a series of experiments summarized in Table 2, under controlled atmospheres mimicking biomass firing conditions. To achieve this, a high temperature corrosion test-rig, schematically shown in Figure 1, was used. The corrosion test-rig consists of a gas mixing compartment, an electrically heated furnace and a 
flue gas cleaning system. Mass flow controllers are used to carefully regulate the concentration of each gas component.

Table 2. Exposure conditions at a temperature of $560^{\circ} \mathrm{C}$. For comparison, conditions for the $168 \mathrm{~h}$ exposure at a similar temperature [44] (reference condition for the present work) is also presented

\begin{tabular}{|c|c|c|c|c|c|c|c|}
\hline \multirow[b]{2}{*}{ Experiment } & \multirow[b]{2}{*}{$\begin{array}{l}\text { Time } \\
\text { (h) }\end{array}$} & \multicolumn{6}{|c|}{ Gas composition } \\
\hline & & $\begin{array}{l}\mathrm{HCl} \\
\text { (ppmv)/dry }\end{array}$ & $\begin{array}{l}\mathrm{SO}_{2} \\
(\mathrm{ppmv}) / \mathrm{dry}\end{array}$ & $\begin{array}{l}\mathrm{CO}_{2} \\
\text { (vol } \\
\% \text { )/dry }\end{array}$ & $\begin{array}{l}\mathrm{O}_{2} \\
\text { (vol } \\
\% \text { )/dry }\end{array}$ & $\begin{array}{l}\mathrm{N}_{2} \\
\text { (vol } \\
\% \text { )/dry }\end{array}$ & $\begin{array}{l}\mathrm{H}_{2} \mathrm{O} \\
\text { (vol } \\
\% \text { ) }\end{array}$ \\
\hline $\begin{array}{l}\text { Condition } \\
1\end{array}$ & 72 & 400 & 60 & 12 & 6 & 82 & 3 \\
\hline $\begin{array}{l}\text { Condition } \\
2\end{array}$ & 72 & 400 & 60 & 12 & 6 & 82 & 13 \\
\hline Reference & 168 & 400 & 60 & 12 & 6 & 82 & 3 \\
\hline
\end{tabular}

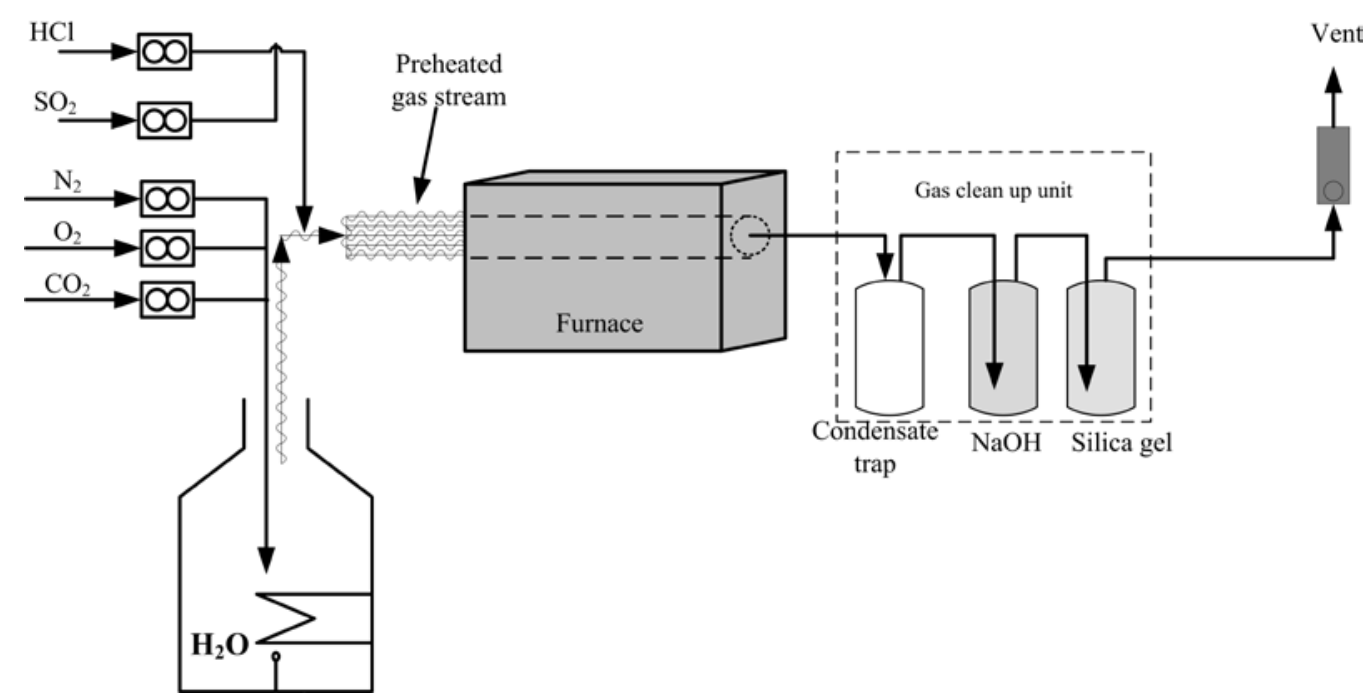

Figure 1. Schematic representation of the high-temperature corrosion test-rig.

The furnace contains five quartz reactors in which the samples were placed. In reactors containing more than one sample, a minimum separation distance of $50 \mathrm{~mm}$ was maintained between the samples to avoid shielding effects. In order to incorporate the desired $\mathrm{H}_{2} \mathrm{O}$ vapour concentration, the gas mixture of $\mathrm{CO}_{2}$, 
$\mathrm{O}_{2}$ and $\mathrm{N}_{2}$ (carrier gas) was passed through a thermally controlled $\mathrm{H}_{2} \mathrm{O}$ bath. The desired $\mathrm{H}_{2} \mathrm{O}$ vapour concentration was obtained by setting the temperature of the bath such that the ratio of vapour pressure of $\mathrm{H}_{2} \mathrm{O}$ at such temperatures to that at $100{ }^{\circ} \mathrm{C}$ gave the desired concentration. The $\mathrm{H}_{2} \mathrm{O}$ loaded gas mixture was finally mixed with the $\mathrm{HCl}$ and $\mathrm{SO}_{2}$ gas streams and then fed into the reactors in a preheated channel to avoid condensation. At the exit of each reactor, ball flowmeters are connected in order to maintain a uniform gas flow in each reactor. All exposures were carried out isothermally at $560{ }^{\circ} \mathrm{C}$. After each exposure, the samples are allowed to cool down under a flow of humid $\mathrm{N}_{2}$. A minimum of 6 samples were exposed at each experimental condition shown in Table 2.

The experiments reported here focus on the effect of parameters relevant for high temperature corrosion in biomass plants. However in the real plant, there are many fluctuating parameters, such as gas and metal temperatures, thermal gradient, flue gas composition, dynamic flow within the boiler which can make it difficult to understand the specific roles of the different corrosive components. Also, it is a simplification of the corrosion process to have isothermal exposures using only a $\mathrm{KCl}$ deposit. However, this is undertaken to obtain specific mechanistic data.

\subsection{Characterization of exposed samples}

The corrosion products formed on the samples were characterized by means of microscopic, spectroscopic and diffraction techniques. Characterization involved both examination of the cross sections, and plan-view investigations coupled with mechanical removal of the corrosion products (in the case of deposit-coated samples).

To facilitate cross-sectional investigations on exposed deposit-coated samples, a two-stage process for metallographic embedding was employed. First, the samples were mounted in the as-exposed condition under vacuum using an epoxy based resin. This preserved the as-exposed morphology of the corrosion products. Subsequently, mounted samples were sectioned under dry conditions to assess the cross-section of the samples. A second stage mounting under vacuum using an epoxy based resin was carried out with the exposed cross-section facing downwards in the mount. The mounted samples were then prepared according to standard metallographic techniques down to $1 \mu \mathrm{m}$ diamond suspension. During the metallographic preparation process, the samples did not come in contact with water; instead, absolute ethanol (99.9 \%, VWR Chemicals) was used as a lubricant to prevent dissolution of the water-soluble corrosion products (such as metal chlorides).

For deposit-free samples, a direct mounting under vacuum in epoxy was carried out. The mounted samples were also prepared according to the water-free techniques utilized for the deposit-coated samples. 
Plan-view investigations of the deposit-coated samples started directly on the exposed deposit surface and continued with subsequent characterization of the revealed interfaces after stepwise mechanical removal of the corrosion products. Owing to the thin corrosion products observed on deposit-free samples, only direct plan-view surface investigations on the as-exposed samples were carried out.

Both plan-view and cross section analysis was carried out with scanning electron microscopy (SEM). This microscopic analysis of the morphology of the corrosion scale and the microstructure of the steel beneath the affected surface was combined with chemical element analysis applying energy dispersive spectroscopy (EDS) in the SEM. The prepared cross-sections were coated with carbon prior to SEM analysis.

For all SEM (Inspect S, FEI) investigations, an acceleration voltage of $15 \mathrm{keV}$ and a beam spot size of 5 were used. Micrographs were obtained using the backscatter electron (BSE) detector in order to reveal information from the compositional contrast of the corrosion products. For some plan-view investigations, BSE images were supplemented by secondary electron (SE) imaging.

Quantitative elemental compositions of the corrosion products were revealed with an EDS (Oxford instruments) system attached to the SEM. An acceleration voltage of $15 \mathrm{keV}$ was also utilized for EDS measurements. Due to the heterogeneous surface morphology of the corrosion products, EDS results are shown only for values above $1 \mathrm{wt} \%$ to minimize possible errors. Also, due to possible contamination from the metallographic preparation and mechanical removal steps using SiC grinding paper, Si was intentionally not analysed.

Crystalline corrosion products were identified by qualitative phase analysis using X-ray diffraction (XRD). The diffractometer (Bruker AXS, D8 Discover) was operated with Cr-K $\alpha$ radiation. An asymmetric beam path (grazing incidence geometry) with a fixed incidence angle of $\gamma=2{ }^{\circ}$ was employed for XRD. These diffraction measurements were further combined with stepwise removal of corrosion products, where each removal was larger than the maximum X-ray penetration depth during grazing incidence measurements. Due to the geometry of the samples, measurements were carried out with a point focused incidence beam using a polycap optics system.

\section{Results}

\subsection{Reference exposure (straw-firing flue gas, 3 vol \% $\mathrm{H}_{2} \mathrm{O}, 168 \mathrm{~h}$ )}

A similar exposure of the same alloy (TP 347H FG) coated with the same deposit (KCl) at the same temperature $\left(560^{\circ} \mathrm{C}\right)$ for $168 \mathrm{~h}$ to straw-firing flue gas composition containing $3 \mathrm{vol} \% \mathrm{H}_{2} \mathrm{O}$ has been previously reported [44]. For comparison, selected results of this previous study are summarized in 
Figure S1(see supporting information) as they form the basis for discussion of results from the present samples. These results originate from the examination of more than 10 samples and are representative of the corrosion morphology. As observed from the various micrographs, the morphology of the corrosion products is not uniform. However, a general observation is the occurrence of three layers of corrosion products (Figure S1, a-d in the supporting information). Layer 1 and layer 2 are similar in all samples, while layer 3 exhibits some variation. Detailed characterization revealed that layer 1 consists of $\mathrm{K}_{2} \mathrm{SO}_{4}$ $\mathrm{KCl}-\mathrm{Fe}_{\mathrm{x}} \mathrm{O}_{y}$, while layer 2 consists of mainly $\mathrm{M}_{\mathrm{x}} \mathrm{O}_{\mathrm{y}} ; \mathrm{M}=\{\mathrm{Fe}, \mathrm{Cr}\}$ [44]. A sponge like Ni-S-rich microstructure dominated in layer 3 (Figure S1 a). In addition to Ni and S, Cr and Fe could be identified within layer 3 on some locations (Figure S1 b-d). However, such regions did not exhibit a clear porous structure but rather a continuous layer or pit like morphology. Irrespective of the morphology of layer 3 , the presence of a Ni-rich band at the interface between the corrosion product and the bulk of the alloy was always observed from EDS mapping across the cross section. Preferential attack along grain boundaries is often observed below layer 3 of the corrosion product. Detailed microstructure characterization of the corrosion products resulting from exposure under this condition is contained in Okoro et. al. 2014 [44].

\subsection{Exposure under straw-firing flue gas with 3 vol. \% $\mathrm{H}_{2} \mathrm{O}$ (condition 1, 72 h)}

The exposure of deposit-coated samples to flue gas containing $3 \mathrm{vol} \% \mathrm{H}_{2} \mathrm{O}$ for $72 \mathrm{~h}$ (condition 1 in Table 2) resulted in the formation of the corrosion products shown in Figure $2 a-d$, illustrating their nonuniform nature. Consistently, however, the corrosion products observed below the initial deposit consist of three layers marked as 1, 2, and 3 in the micrographs.

The corresponding elemental composition of the corrosion products revealed by EDS mapping are presented in the Figures 3a - c. Layer 1 appears similar to that observed after the reference exposure (cf. Figure S1 in supporting information). This layer consistently contains Fe, K, S and O regardless of the overall morphology of the corrosion product. Similarly, layer 2 also consistently is comprised of $\mathrm{Fe}, \mathrm{Cr}$ and $\mathrm{O}$. However, the $\mathrm{Cr}$ maps show that $\mathrm{Cr}$ is enriched in the lower parts of layer 2. The morphology of layer 3 is rather non-uniform. Observations from this layer are summarized as follows:

- Double layered regions (Figure 2a) with a very porous upper layer, and a relatively continuous layer below. Such regions are comprised of Fe, Cr, Ni, O and S (Figures 2a and 3a). A number of pores can be identified also in the lower layer (Figures $2 \mathrm{~b}$ and $3 \mathrm{~b}$ ).

- $\quad$ Fe, Cr, Ni, O and S containing pits (Figures 2c and 3c).

- Regions with a dual-layered morphology similar to (i), but with selective attack along grain boundaries extending into the bulk of the alloy (Figure 2d). The EDS line scans (not shown here) 
along such grain boundaries reveal $\mathrm{Fe}$ and $\mathrm{Cr}$ depletion, with a corresponding enrichment of $\mathrm{Ni}, \mathrm{S}$ and $\mathrm{O}$.
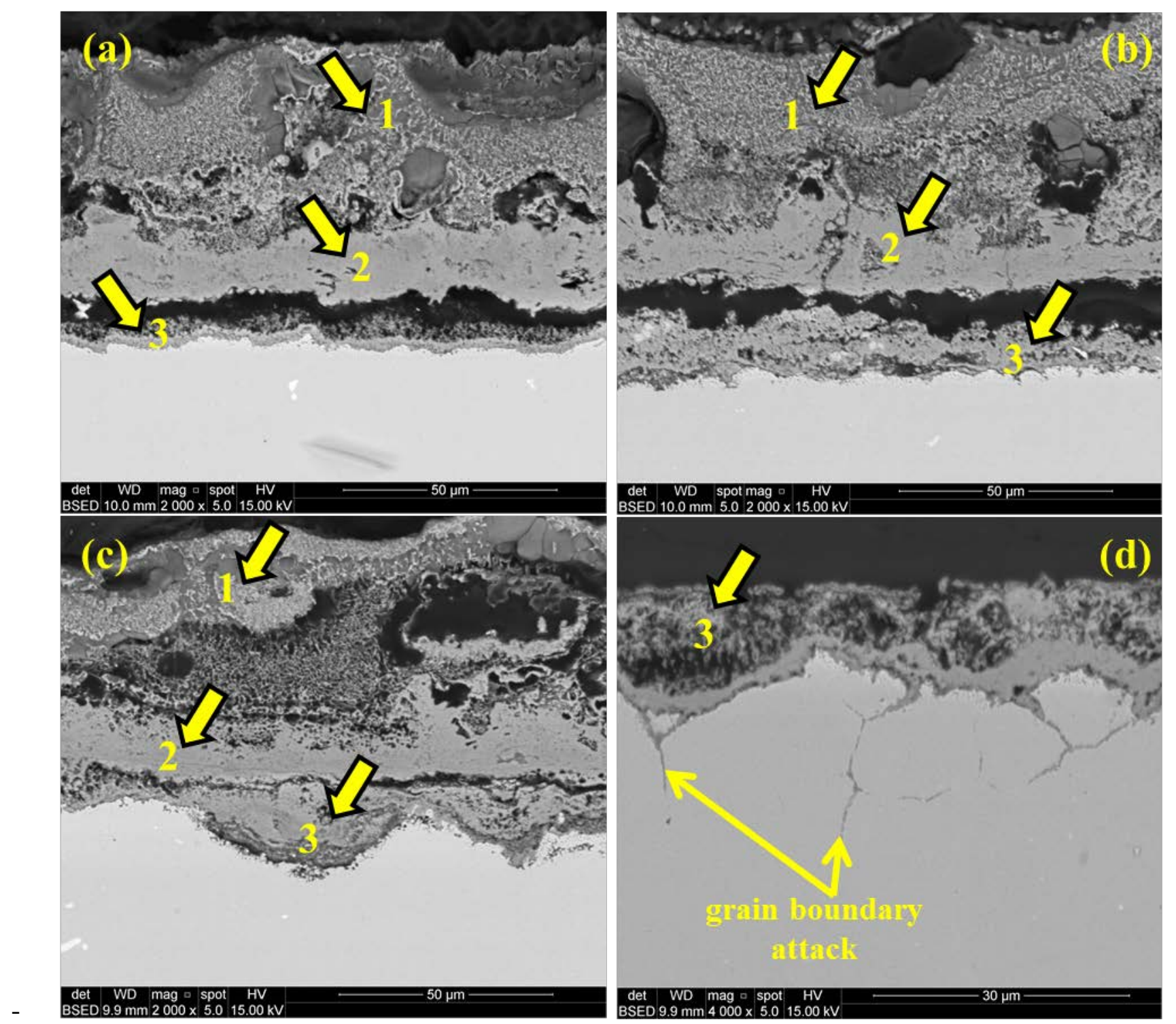

Figure 2. Selected cross sections of corrosion product resulting from exposure to condition 1 (flue gas with $3 \mathrm{vol} \% \mathrm{H}_{2} \mathrm{O}$ ) (1: layer-1, 2: layer-2, 3: layer-3). Micrographs in a) to d) refer to different locations on the exposed samples. 

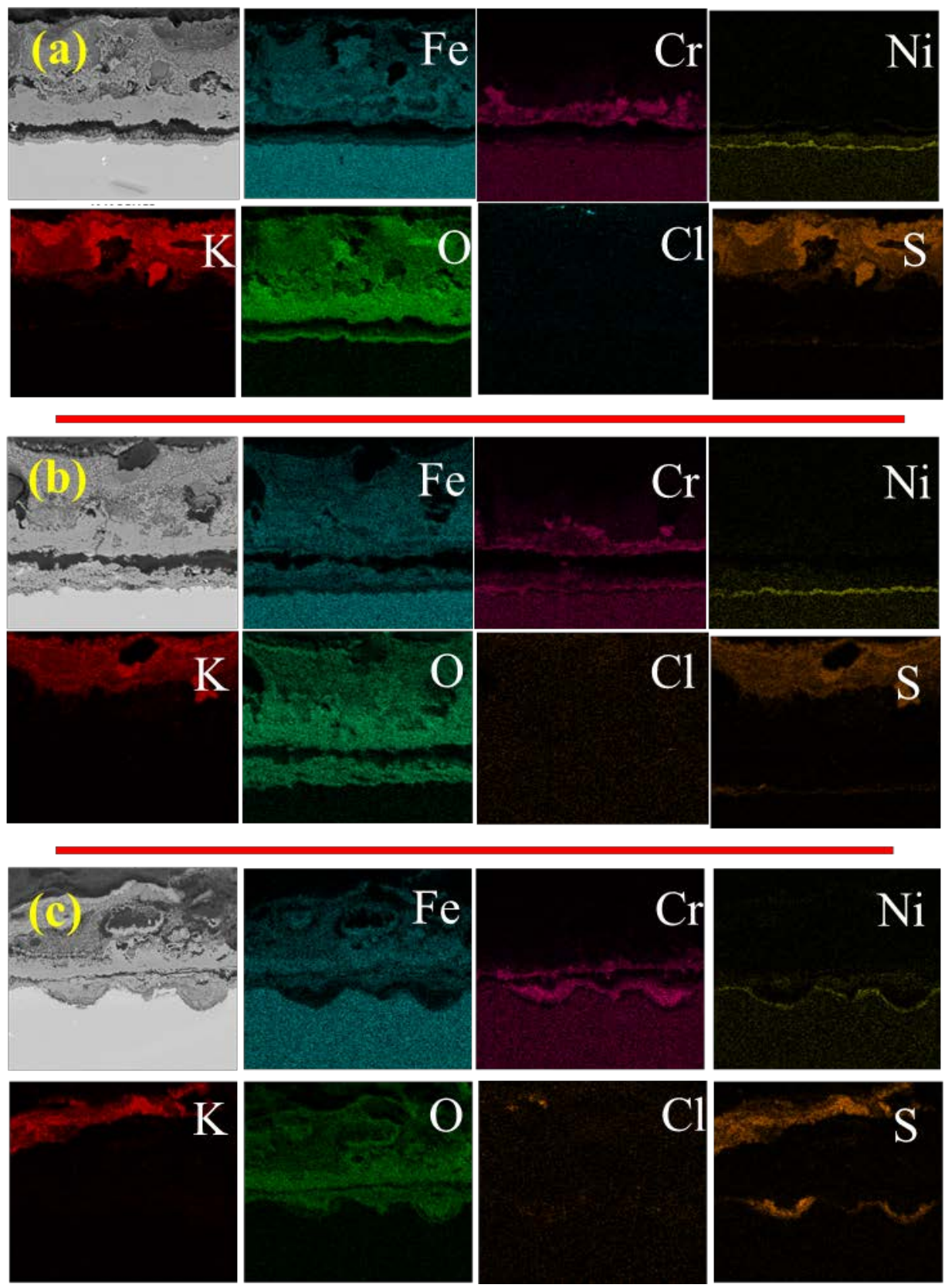

Figure 3. EDS maps showing elemental composition of the corrosion products resulting from exposure under condition 1 (flue gas with $3 \mathrm{vol} \% \mathrm{H}_{2} \mathrm{O}$ ). Maps in a) to c) refer to different locations on the exposed samples, cf. Fig. 2. 
More detailed results on the morphology and composition of the corrosion products are obtained from plan-view characterization, combined with mechanical removal of the corrosion product layers. In Figures $4 \mathrm{a}$ and $\mathrm{b}$, plan-view microstructures of the deposit observed from the flue gas/deposit and deposit/corrosion product interfaces are shown respectively.
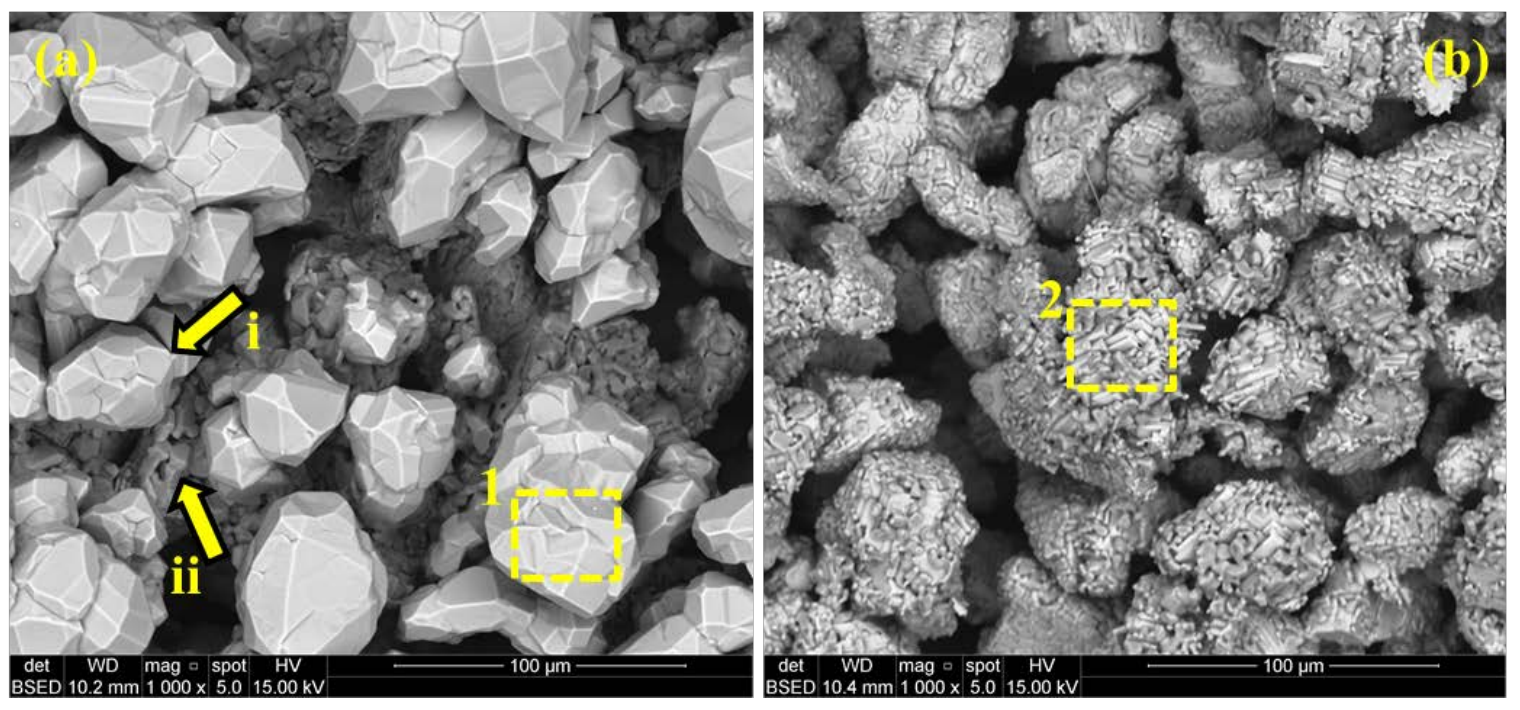

Figure 4. Plan view microstructure of the synthetic deposit at the flue gas/deposit (a) and deposit/corrosion product (b) interfaces after exposure to condition 1 (flue gas with $3 \mathrm{vol} \% \mathrm{H}_{2} \mathrm{O}$ ). For elemental composition of locations 1 and 2, see Table S1 in the supporting information.

At the flue gas/deposit interface, large facetted particle agglomerates consisting exclusively of $\mathrm{K}, \mathrm{S}$ and $\mathrm{O}$ are detected (Table S1, supporting information). The size of these particle agglomerates decreases with distance from the flue gas/deposit interface into the bulk of the deposit (see arrows (i) and (ii) in Figure 4a). Deeper in the deposit, these features agglomerate around the initial deposit particles. Similarly, examination of the deposit particles from the deposit/corrosion product interface (Figure $4 \mathrm{~b}$ ) also revealed accumulation of these $\mathrm{K}, \mathrm{S}$ and $\mathrm{O}$ rich features around the $\mathrm{KCl}$ deposit particles but to a reduced extent. This observation supports the identification of $\mathrm{Cl}$ from the deposit particles in the EDS analysis shown in Table S1 (supporting information). After partial removal of the surface deposit, the Fe, K, S and $\mathrm{O}$ containing layer shown in Figure 2 (layer 1 ) is seen to accumulate around the $\mathrm{KCl}$ deposit particles (Figure 5 and location 1 and 2 in Table S2, supporting information). EDS analysis on positions where the initial $\mathrm{KCl}$ particles have been removed (location 3 in Table S2) reveal high concentration of Fe (61.4 wt \%), in addition to $\mathrm{Cr}$ and Mn. Previously identified elements (K, S and O) from the maps in Figure 3 were also revealed by plan-view EDS analysis.

Figure 6 shows secondary electron (SE) plan-view micrographs of corrosion products obtained after removal of the $\mathrm{M}_{\mathrm{x}} \mathrm{O}_{\mathrm{y}}-\mathrm{K}-\mathrm{S}-\mathrm{O}$ deposit-coated layer shown in Figure $5(\mathrm{M}=\{\mathrm{Fe}, \mathrm{Cr}, \mathrm{Mn}\})$. EDS analysis 
(location 1 in Table S3, supporting information) revealed that this layer consists mainly of $\mathrm{M}_{\mathrm{x}} \mathrm{O}_{\mathrm{y}}$; where $\mathrm{M}=\{\mathrm{Fe}, \mathrm{Cr}, \mathrm{Mn}\}$.
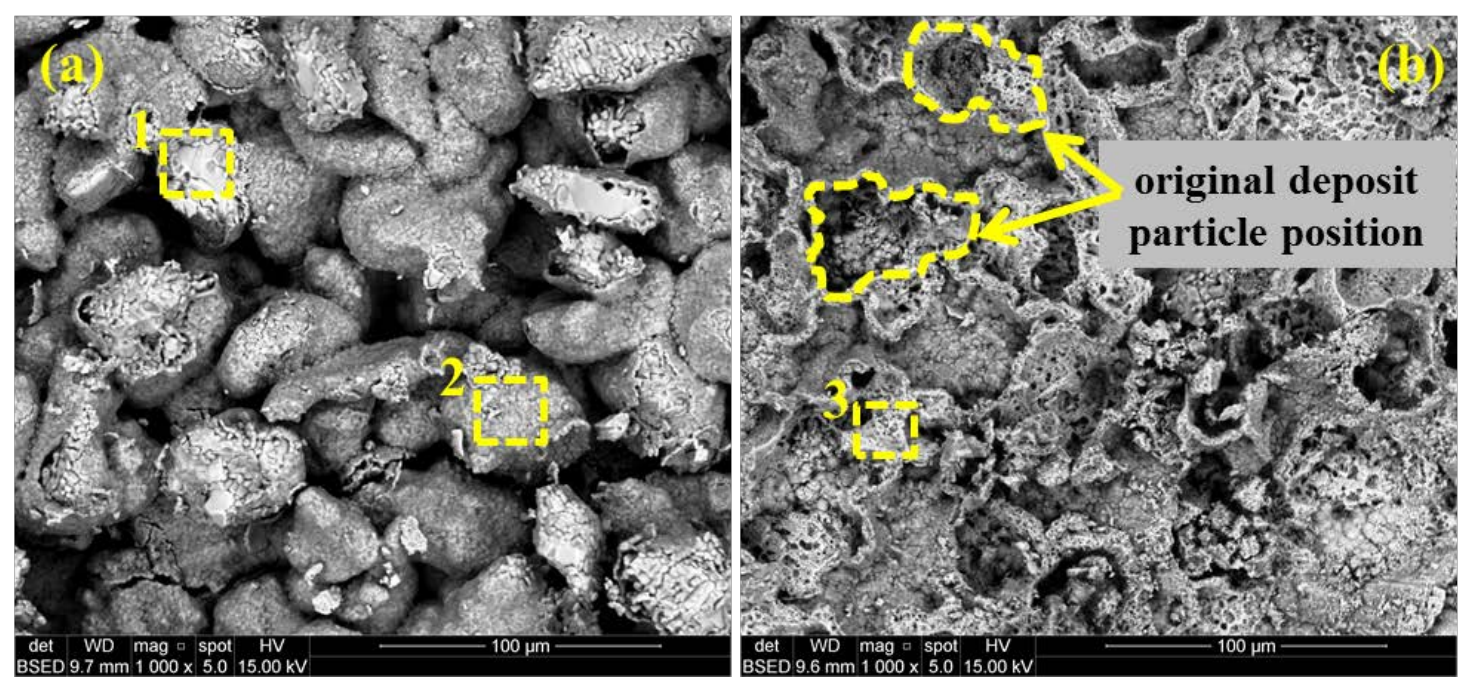

Figure 5. Selected plan view micrographs of the corrosion product showing the observed microstructure after partial removal of the initial $\mathrm{KCl}$ deposit, i.e. beneath surfaces shown in Fig. 4, on a sample exposed to condition 1. For elemental composition of locations 1-3, see Table S2 in the supporting information.
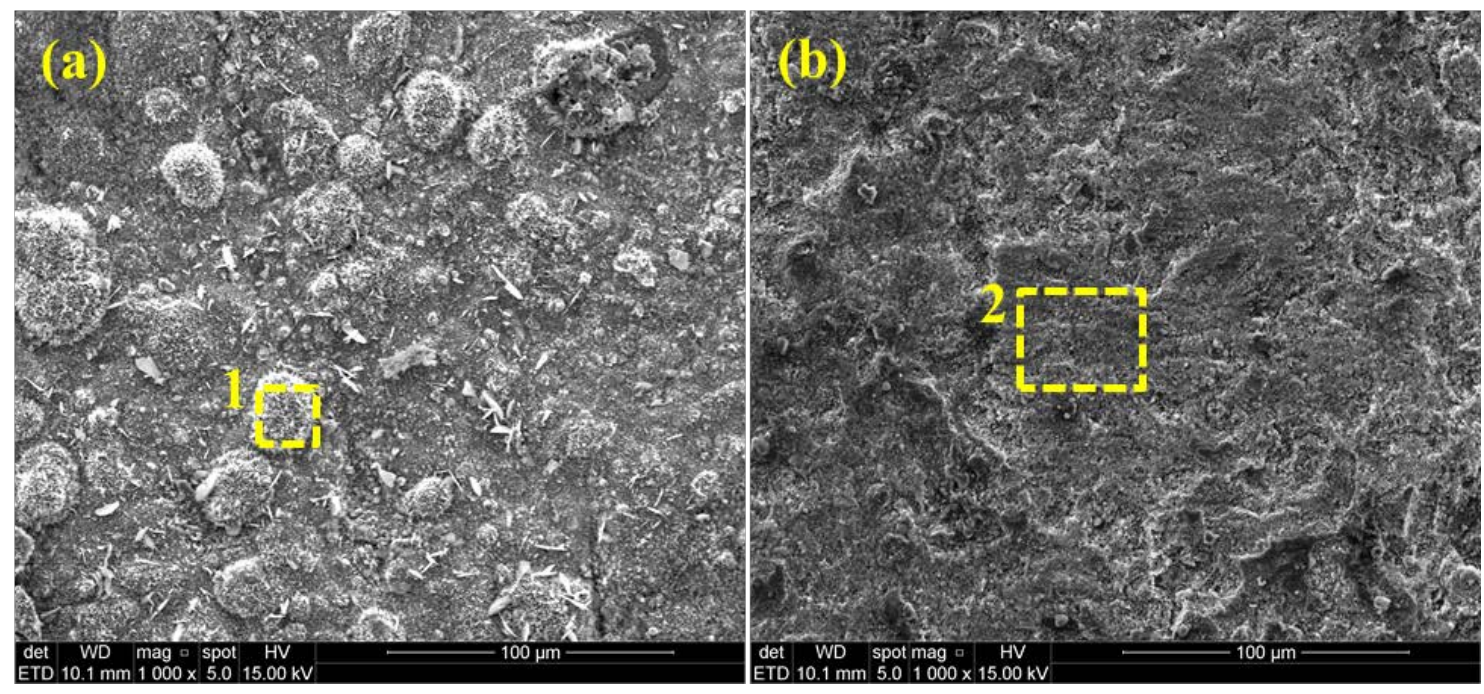

Figure 6. Selected plan view microstructures (SE images) of the corrosion product observed directly below the $\mathrm{KCl}-\mathrm{K}_{2} \mathrm{SO}_{4}$ rich layer in Figure 5, after further removal of the corrosion product resulting from exposure to condition 1. For elemental composition of locations 1 and 2, see Table S3 in the supporting information. 
The Fe-rich layer (Figure 6a) is observed to contain isolated nodular as well as blade-like structures. After removal of the Fe-rich layer, the revealed corrosion product layer in Figure 6b is Cr-rich (location 2 in Table S3). These results agree with that revealed by EDS mapping on the cross-section of the corrosion product (cf. Figure 3), i.e. outer Fe-rich oxide and inner $\mathrm{Cr}$ rich oxide.

Plan-view BSE images of regions where the internal attack occurred are shown in Figure 7 and supplemented by EDS results in Table S4 (supporting information). More than $20 \mathrm{wt} \%$ of each of the alloying elements $\mathrm{Fe}, \mathrm{Cr}$ and $\mathrm{Ni}$ were present in the internally attacked zones. The analysis reveals that $\mathrm{Cr}$ and $\mathrm{Ni}$ are enriched in these regions compared to the bulk alloy and that Fe is depleted. In addition, small amounts of chlorine and large amounts of oxygen were also identified. Also at these positions, attack along grain boundaries was observed (Figure 7b).
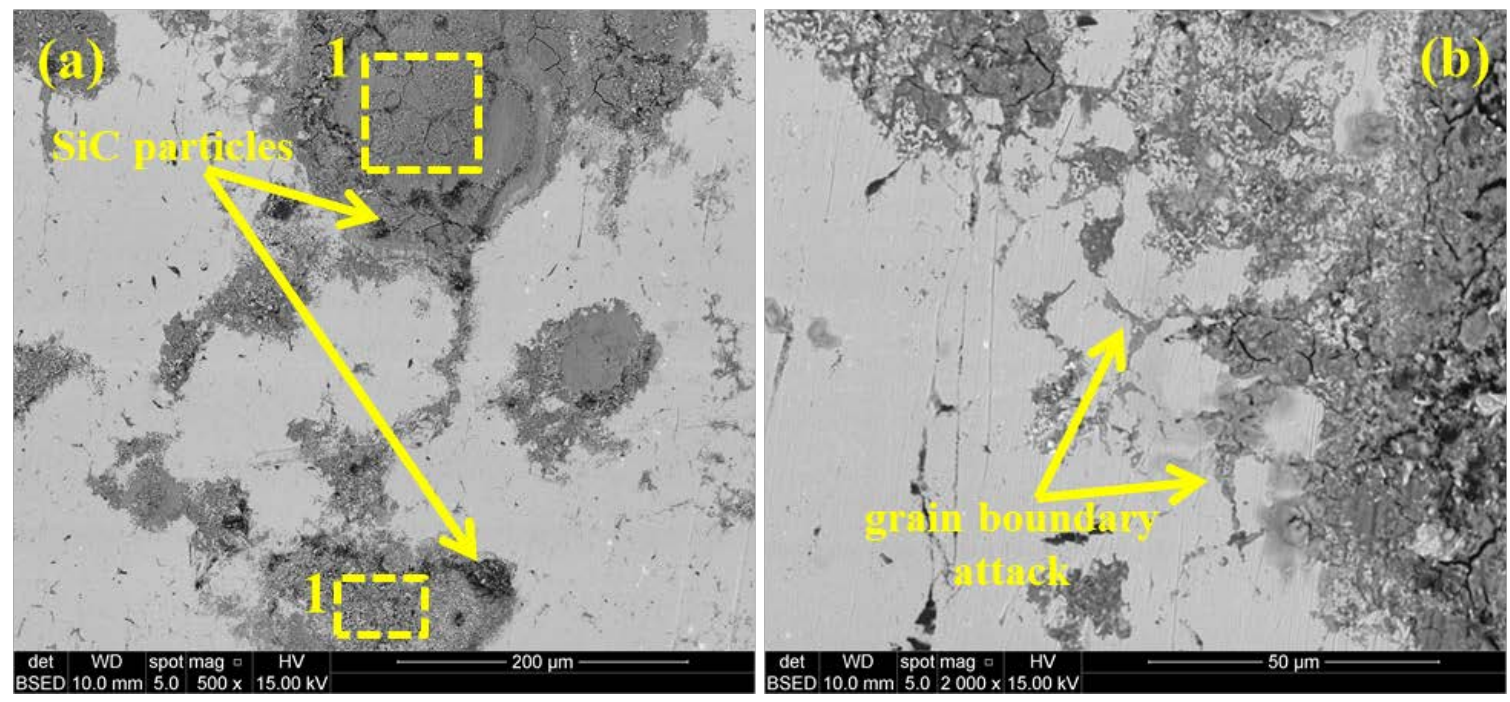

Figure 7. BSE plan view microstructure of regions of internal attack (close to the corrosion front) due to exposure to condition 1. For average elemental composition of location 1, see Table S4 in the supporting information.

Results from grazing incidence XRD (GI-XRD) measurements after the stepwise removal of the corrosion products are shown in Figure 8. The rough morphology of the corrosion product (cf. Figure 5) resulted in a high signal to noise ratio in the diffractograms. Nonetheless, both KCl (JCPDS card 411476) and $\mathrm{K}_{2} \mathrm{SO}_{4}$ (JCPDS card 05-613) could be identified in the diffractogram obtained from the sulphated deposit layer (cf. Figure 5). On the Fe-rich layer shown in Figure 6a, $\mathrm{Fe}_{2} \mathrm{O}_{3}$ (JCPDS card 33664 ) was the predominant crystalline phase identified. Apart from the austenite phase ( $\gamma$-Fe, JCPDS card 33-397), no other phase could be detected in the diffractogram recorded at the regions of internal attack (cf. Figure 7). 


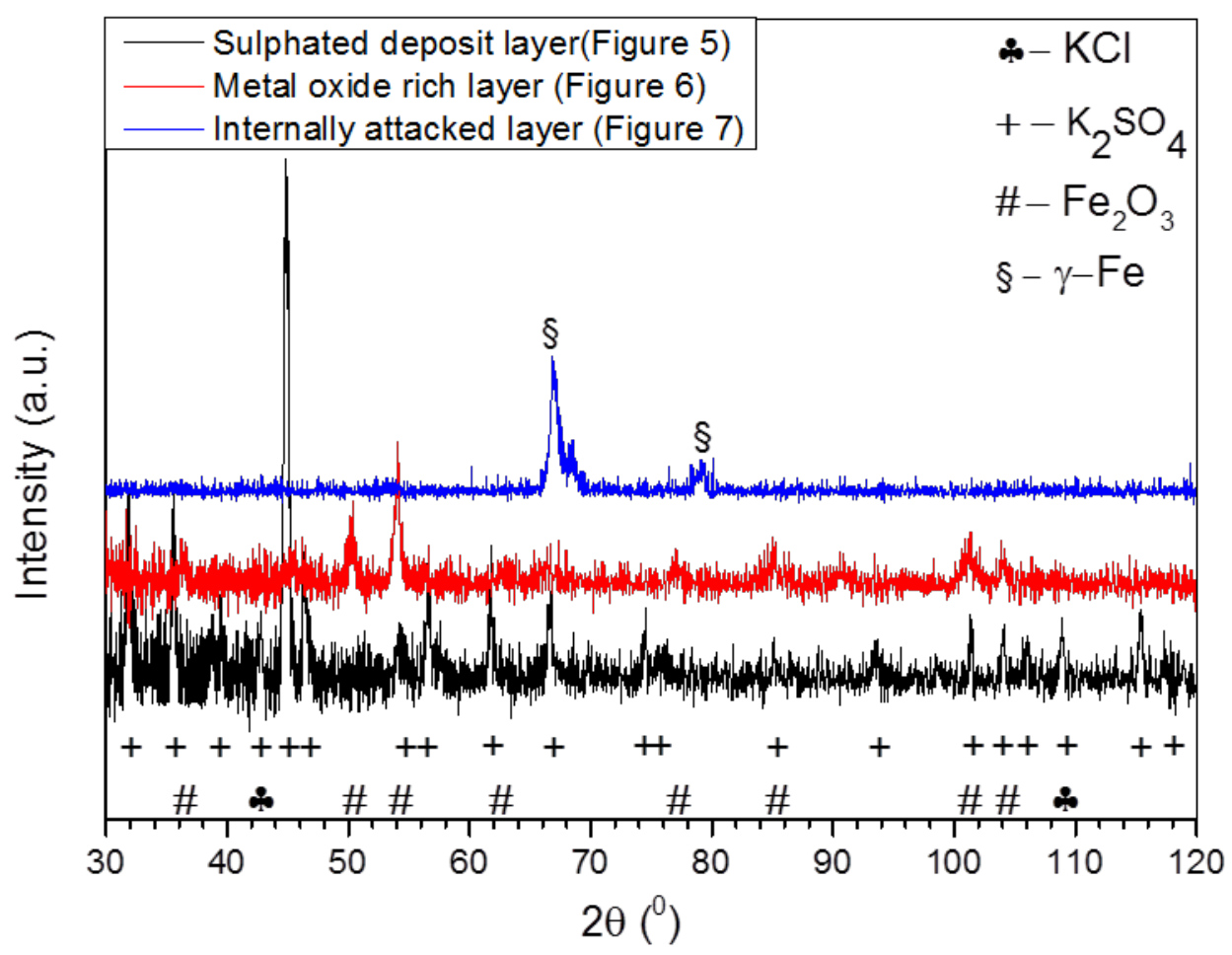

Figure 8. Grazing incidence XRD diffractograms showing the predominant crystalline corrosion product phases (after exposure to condition 1) on the different layers of corrosion product shown in Figures 5, 6 and 7. The peak at $\sim 69^{0}$ is due to stress-induced austenite to martensitic transformation during mechanical removal.

The corrosion products resulting from exposure under the same flue gas condition, but on deposit-free samples are shown in Figure 9. The plan-view investigation indicates that the corrosion product includes regions with thicker, coarse and blade-like features with increased concentration of Fe and Mn (Figure 9a, location 1 in Table 3) compared to regions with relatively finer morphological features and greater $\mathrm{Cr}$ and Ni concentration (Figure 9b, location 2 in Table 3). Examination of the cross section (not shown here) showed a thinner layer of corrosion product relative to the deposit coated samples. The elemental composition revealed by EDS mapping (Figure 9c) showed that the corrosion product consists of $\mathrm{Fe}$, $\mathrm{Cr}$ and $\mathrm{O}$. However, only $\mathrm{O}, \mathrm{Cr}$ and $\mathrm{Ni}$ maps are shown here in order to show the differences between the thick and thinner corrosion product regions. Discrete enrichment of Ni was also observed by EDS mapping on the cross sections at the interface between the corrosion product and the bulk of the alloy. The predominant crystalline phase identified by GI-XRD (Figure 10) on the exposed samples was $\mathrm{Fe}_{2} \mathrm{O}_{3}$ (JCPDS card 33-664), in addition to peaks from the bulk sample ( $\gamma$-Fe, JCPDS card 33-397). 

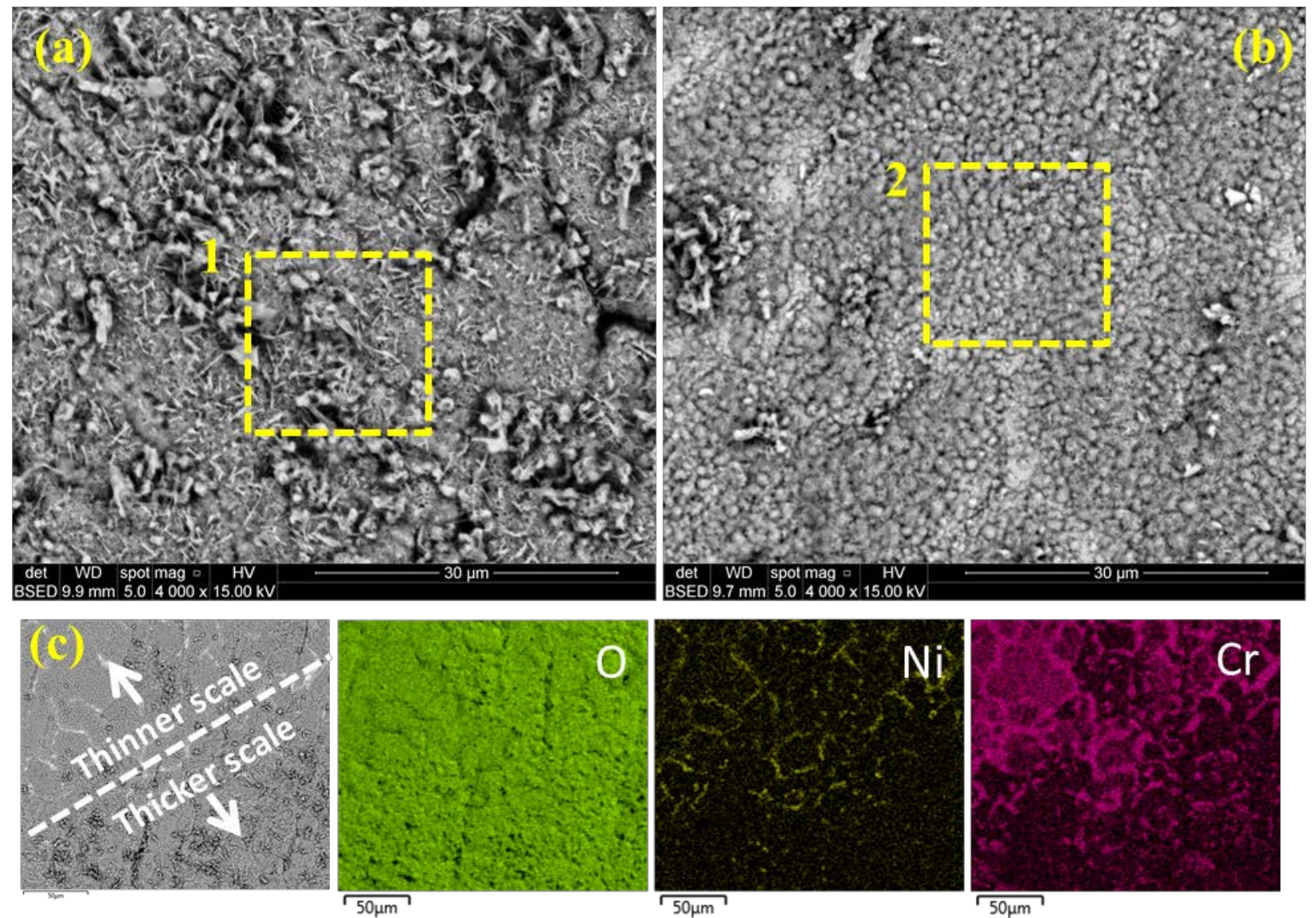

Figure 9. Plan-view (a), (b) and EDS maps (c) of resulting corrosion products on deposit-free samples after exposure to condition 1 (without $\mathrm{KCl}$ deposit, straw-firing flue gas with $3 \mathrm{vol} \% \mathrm{H}_{2} \mathrm{O}$ ). For elemental composition of locations 1 and 2, see Table 3.

Table 3. Elemental composition of selected locations of the corrosion product in Figure 9

\begin{tabular}{llllll}
\hline \multirow{5}{*}{ location } & \multicolumn{5}{l}{ elemental composition (wt \%) } \\
& $\mathrm{O}$ & $\mathrm{Cr}$ & $\mathrm{Mn}$ & $\mathrm{Fe}$ & $\mathrm{Ni}$ \\
1 & 27.7 & 4.3 & 2.3 & 63.7 & - \\
2 & 26.6 & 9.2 & 1.8 & 59.4 & 2.7 \\
\hline
\end{tabular}




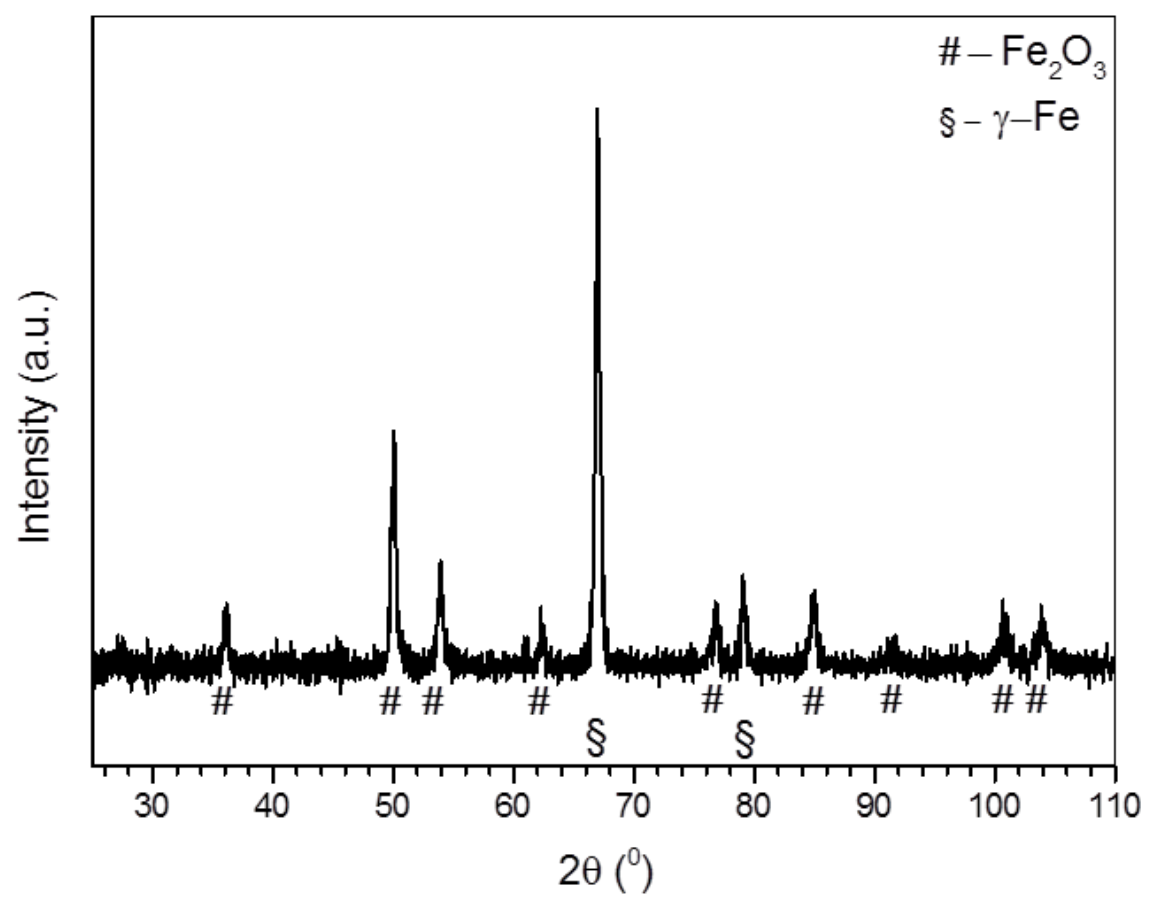

Figure 10. GI-XRD diffractogram showing the predominant crystalline corrosion product phases on deposit-free sample exposed to condition 1.

\subsection{Exposure under straw-firing flue gas with $13 \mathrm{vol} \% \mathrm{H}_{2} \mathrm{O}$ (condition 2, $72 \mathrm{~h}$ )}

Exposure with increased $\mathrm{H}_{2} \mathrm{O}$ vapour content in the flue gas resulted in the formation of corrosion products presented in Figure 11, indicating the heterogeneity of the corrosion products, similar to observations for the previous exposure (cf. Figure S1 in supporting information and Figure 2). Again, three corrosion product layers can be identified as indicated in the micrographs.

Similar to the corrosion products observed in condition 1, layer 1 also consists of Fe, K, S and O (see Figure 12a-c). Fe, $\mathrm{Cr}$ and $\mathrm{O}$ are the major elements of layer 2. $\mathrm{Cr}$ is observed to be enriched at the lower sections of layer 2 (Figure 12a, b). However on some locations across the cross section, $\mathrm{Cr}$ enrichment forms a significant part of layer 3 (Figure 12c). On other locations, the $\mathrm{Cr}$ enriched sections extend into internal attack (grain boundary attack) towards the alloy bulk (Figure 12a, b).

Layer 3 is sometimes observed as a continuous layer (see Figure 12c), consisting mainly of Cr-rich oxide whereas in the other maps (Figure 12a), the $\mathrm{Cr}$ rich oxide is in localised areas. On some locations on the exposed samples (Figures 11b and 12b), layer 3 is lacking, except for local enrichment of Ni. On locations where layer 3 is observed, the elemental composition consists of $\mathrm{Cr}, \mathrm{Ni}, \mathrm{S}, \mathrm{O}$ and $\mathrm{Fe}$. A general feature 
observed in layer 3 is the enrichment of $\mathrm{Ni}$ as marked with the arrows in Figure 12. Ni enriched regions in the grain interior are observed adjacent to grain boundary attack where $\mathrm{Cr}$ rich oxide penetrates into the alloy.

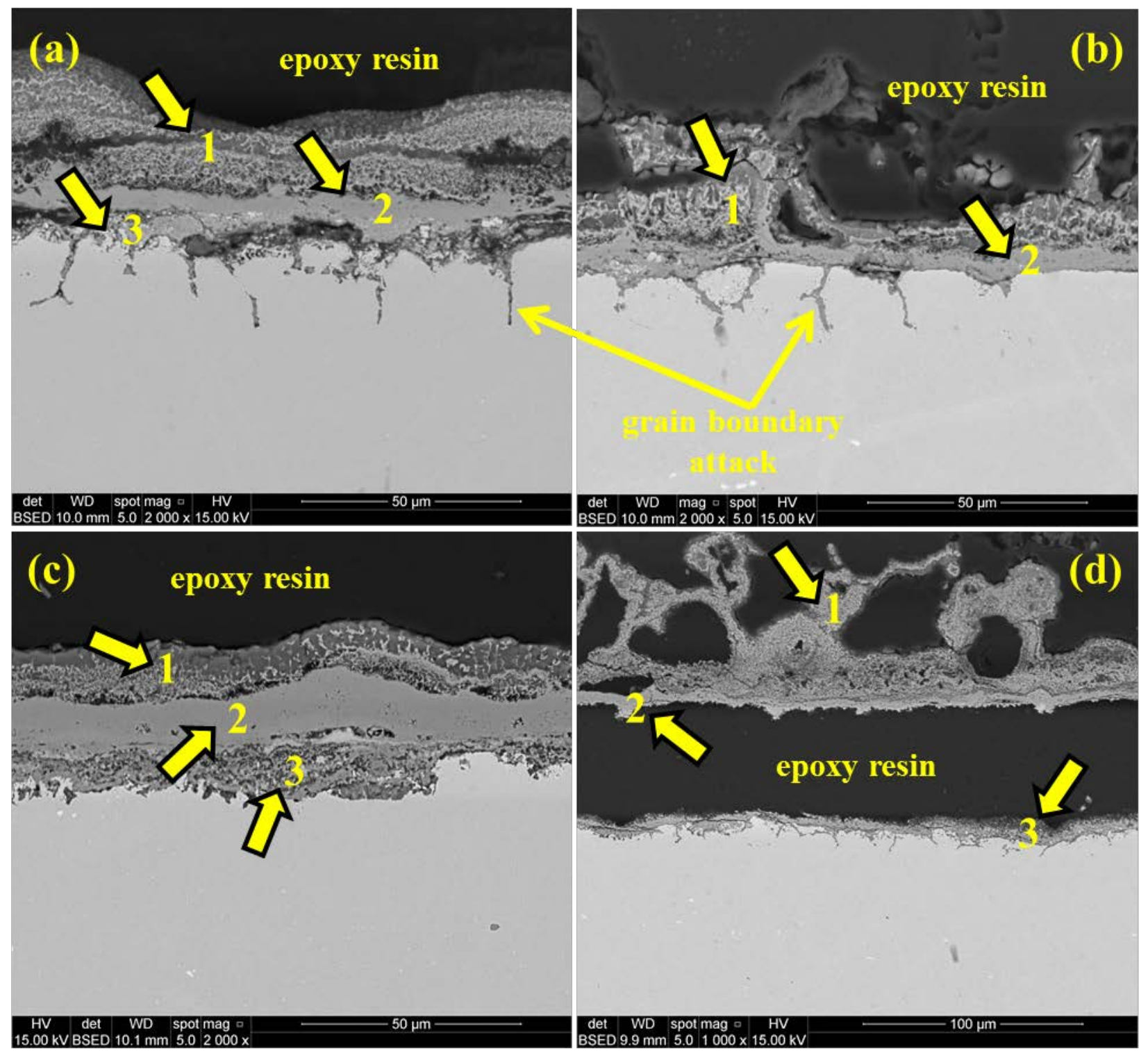

Figure 11. Selected cross sections of the resulting corrosion product after exposure to condition 2 (flue gas with 13 vol\% $\mathrm{H}_{2} \mathrm{O}$ ) (1: layer-1, 2: layer-2, 3: layer-3). Micrographs a)-d) originate from different regions along the sample surface. 

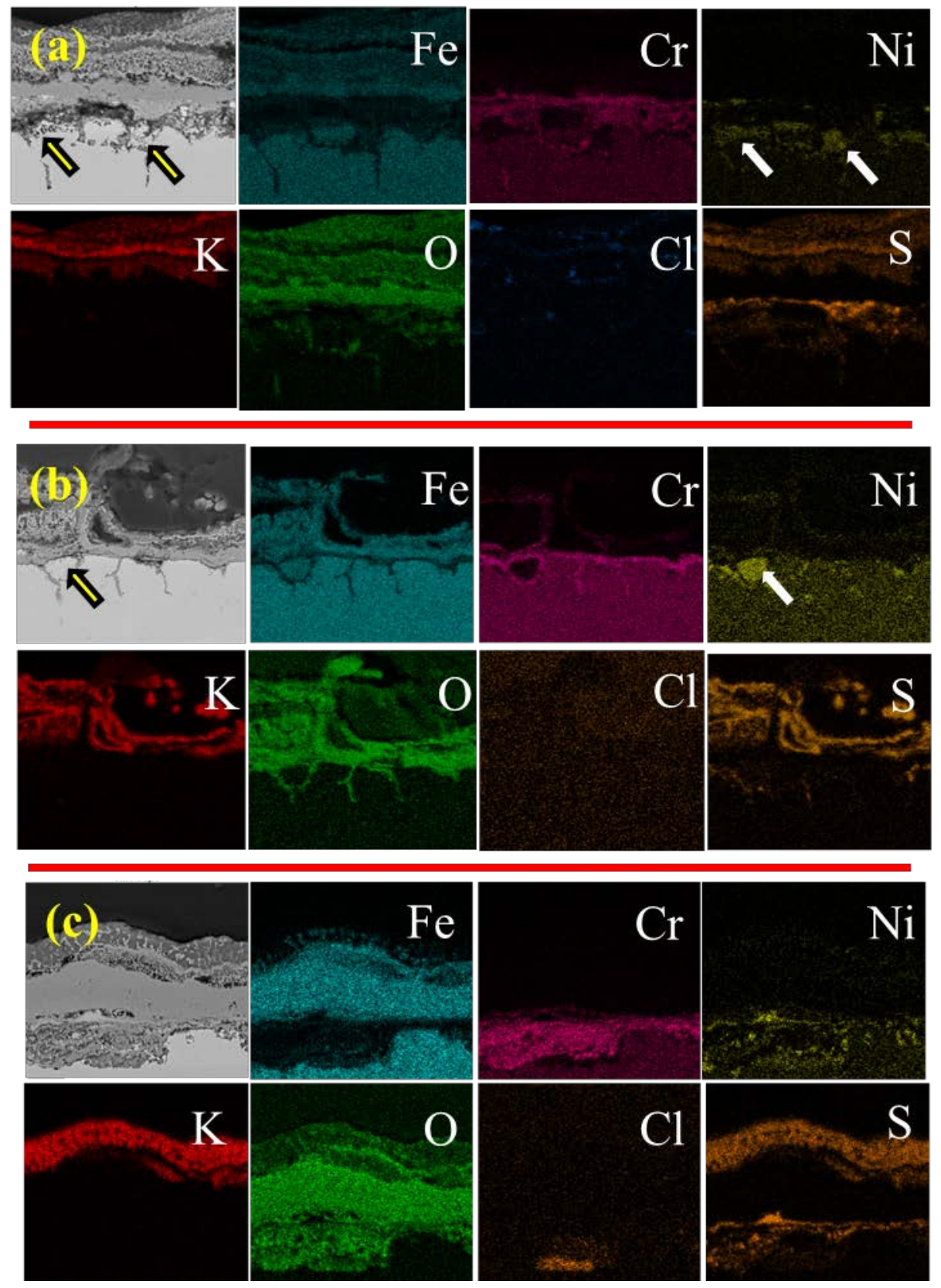

Figure 12. EDS maps showing elemental composition of corrosion products (shown in Figure 11 (a-c)) resulting from exposure to condition 2 (flue gas with 13 vol \% $\mathrm{H}_{2} \mathrm{O}$ ).

EDS line scans (not shown here) reveal a difference in the elemental composition of the attacked grain boundaries as the bulk of the alloy is approached. Grain boundaries extending directly from layer 3 are observed to be depleted in $\mathrm{Fe}$ and $\mathrm{Ni}$, and relatively enriched in $\mathrm{Cr}, \mathrm{O}$ and $\mathrm{S}$. In contrast, the attacked 
grain boundaries closer to the bulk of the alloy are depleted in $\mathrm{Fe}, \mathrm{Cr}$ and $\mathrm{O}$. Instead, only an enrichment of $\mathrm{Ni}$ and $\mathrm{S}$ is observed on such grain boundaries.

In Figures 13 and 14, plan-view micrographs of the corrosion products obtained from stepwise scale removal are presented. Similar to the observation in previous exposure conditions (cf. Figure 4 and the reference exposure [44]), extensive agglomerations are observed around the original deposit particles. These agglomerates fully cover the deposit particles at the flue gas/deposit interface (Figure 13a); hence only $\mathrm{K}, \mathrm{S}$ and $\mathrm{O}$ were identified by EDS. In contrast, partial coverage of the deposit particles is observed at the deposit/corrosion product layer interface (Figure 13b); consequently in addition to $\mathrm{K}, \mathrm{S}$ and $\mathrm{O}, \mathrm{Cl}$ is also identified there.
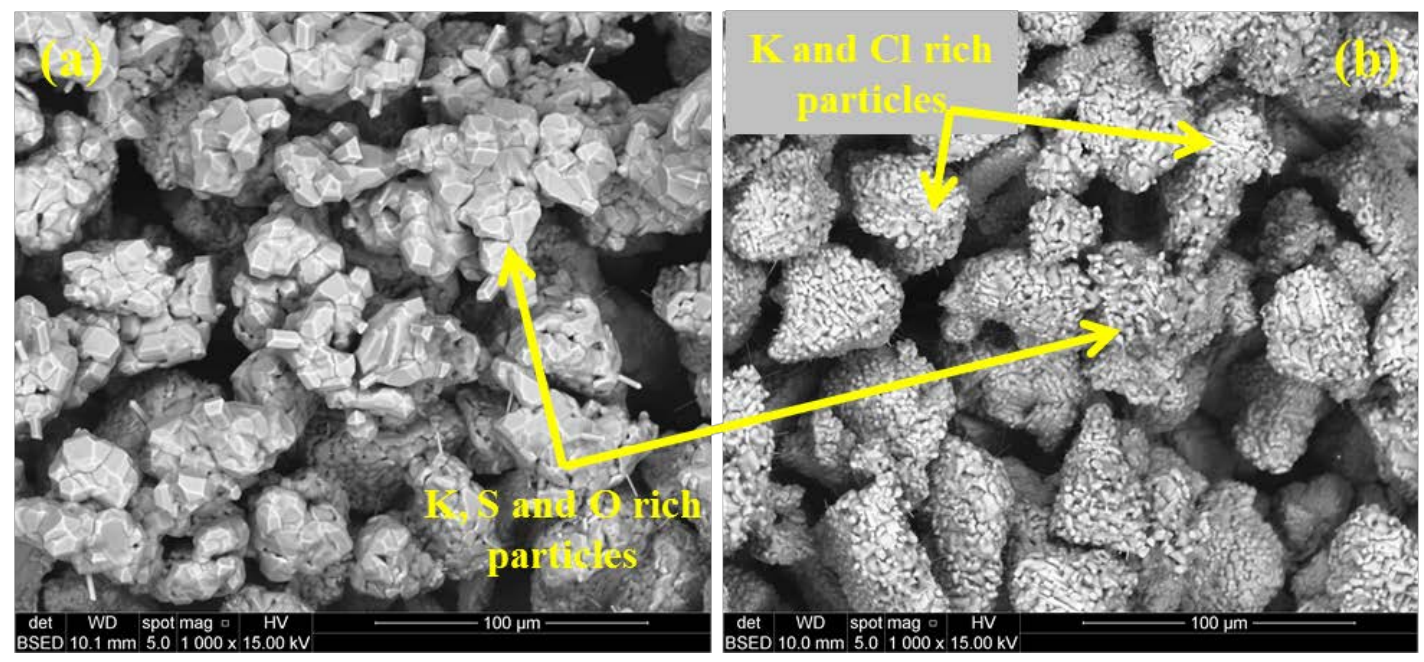

Figure 13. Plan-view microstructure of the synthetic deposit observed from (a) the flue gas/deposit and (b) deposit/corrosion product interfaces after exposure to condition 2 (flue gas with 13 vol \% $\mathrm{H}_{2} \mathrm{O}$ ).

Beneath the deposit particles, the corrosion product layer appears as shown in Figure 14a. This layer also contains partly sulphated particles of the deposit similar to that for the exposure with 3 vol. \% $\mathrm{H}_{2} \mathrm{O}$ in the flue gas (condition 1). Potassium, S, O, Fe, Mn and Ni make up the elemental composition of the continuous regions of this corrosion product layer. On some regions (location 2 in Table 4), it was observed that the initial deposit particles are covered by such continuous regions. In Figure 14b the microstructure of the underside of layer 2 and topside of layer 3 are shown. The underside of layer- 2 consists predominantly of $\mathrm{Cr}$, Fe and $\mathrm{O}$ as previously detected in Figure 12. A correlation is observed between the micrographs in Figure 14b and c. The cross linked features in Figure 14b clearly matches the distribution of the attacked grain boundaries in Figure 14c. A severe case involving selective attack of a complete grain is shown in the insert in Figure 14b. Elemental analysis shows that the corrosion product resulting from such selective attack consists of $\mathrm{Cr}, \mathrm{Fe}, \mathrm{Ni}$, and $\mathrm{O}$, with minor concentrations $(<$ 
2 wt \%) of S and Cl. EDS maps (in Figure S2, supporting information) show that $\mathrm{Fe}$ and $\mathrm{Cr}$ are essentially depleted on the attacked grain boundaries. Instead, a pronounced enrichment of $\mathrm{Ni}, \mathrm{S}, \mathrm{K}, \mathrm{Cl}$ and $\mathrm{O}$ is observed.
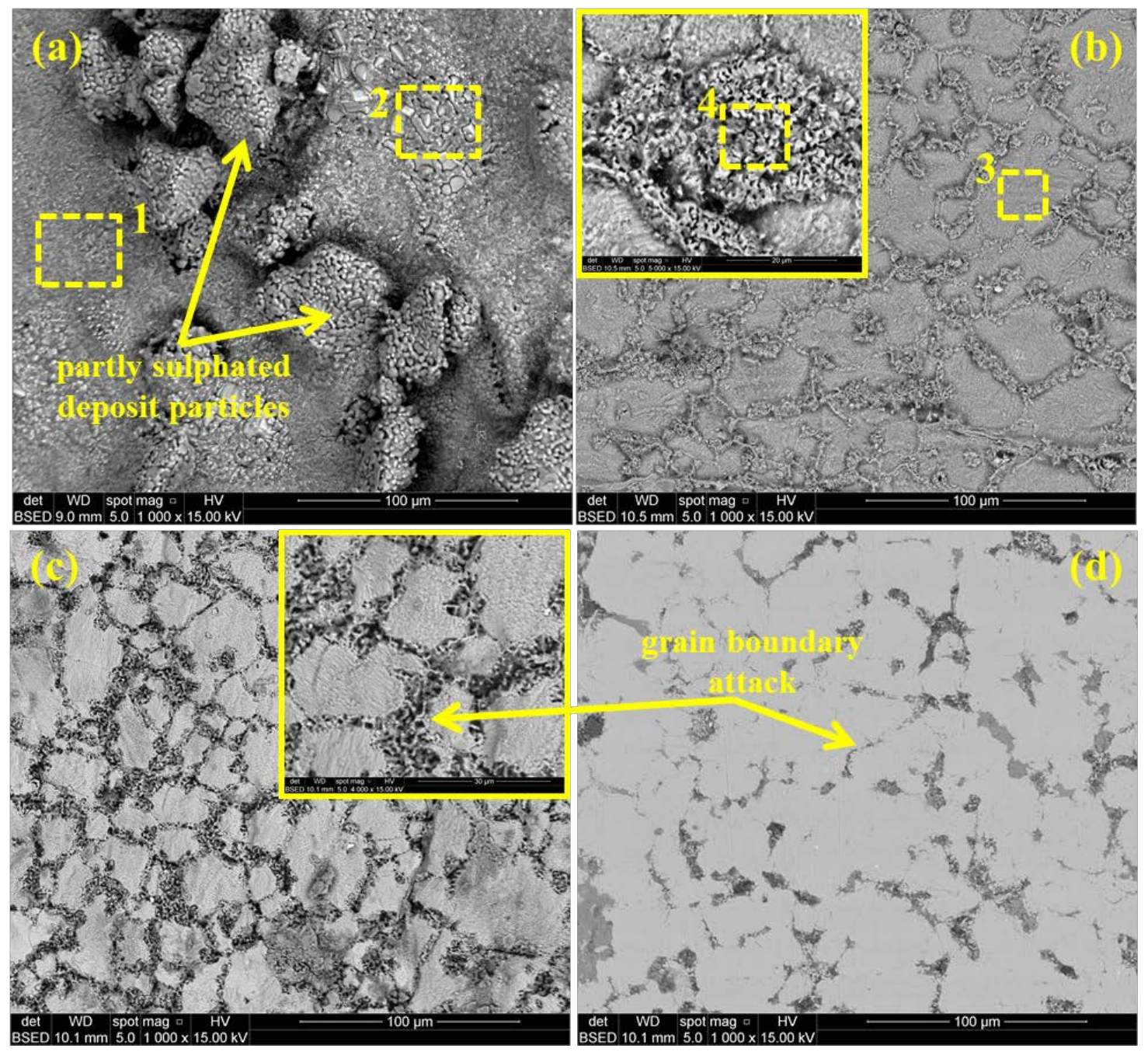

Figure 14. Plan-view microstructures of the corrosion product after exposure to condition 2 (flue gas with $13 \mathrm{vol} \% \mathrm{H}_{2} \mathrm{O}$ ) and stepwise layer removal; (a): observed below the initial deposit, (b): observed from the interface between the corrosion product scale and the alloy bulk, (c), (d): selective attack along grain boundaries as the alloy bulk is approached. 
Table 4. Elemental composition of selected areas in Figure 14

\begin{tabular}{lllllllll}
\hline \multirow{2}{*}{ location } & elemental composition (wt \%) & & & & \\
& $\mathrm{O}$ & $\mathrm{S}$ & $\mathrm{Cl}$ & $\mathrm{K}$ & $\mathrm{Cr}$ & $\mathrm{Mn}$ & $\mathrm{Fe}$ & $\mathrm{Ni}$ \\
1 & 29.8 & 14.4 & - & 34.0 & - & 4.3 & 15.4 & 1.0 \\
2 & 24.0 & 12.4 & 10.4 & 40.5 & - & 9.1 & 3.4 & - \\
3 & 31.4 & - & - & - & 46.3 & - & 19.6 & - \\
4 & 26.3 & 1.8 & 1.9 & - & 36.3 & - & 24.9 & 6.9 \\
\hline
\end{tabular}

The identified crystalline phases of the corrosion product are shown in the diffractograms presented in Figure 15. From the GI-XRD measurements on layer 1 of the corrosion product (cf. Figures 11 and 14a), the phases $\mathrm{KCl}, \mathrm{K}_{2} \mathrm{SO}_{4}$ and $\mathrm{Fe}_{2} \mathrm{O}_{3}$ could be identified according to the JCPDS cards 41-1476, 05-613 and 33-664 respectively. On the revealed surface of the selective attacked layer (layer 3, Figure 14c); both $\mathrm{K}_{2} \mathrm{SO}_{4}$ and $\mathrm{Fe}_{2} \mathrm{O}_{3}$ were identified. In addition, peaks from the alloy bulk ( $\gamma$-Fe, JCPDS card 33397) are detected. With increasing depths, the $\gamma$-Fe phase becomes the predominant phase.

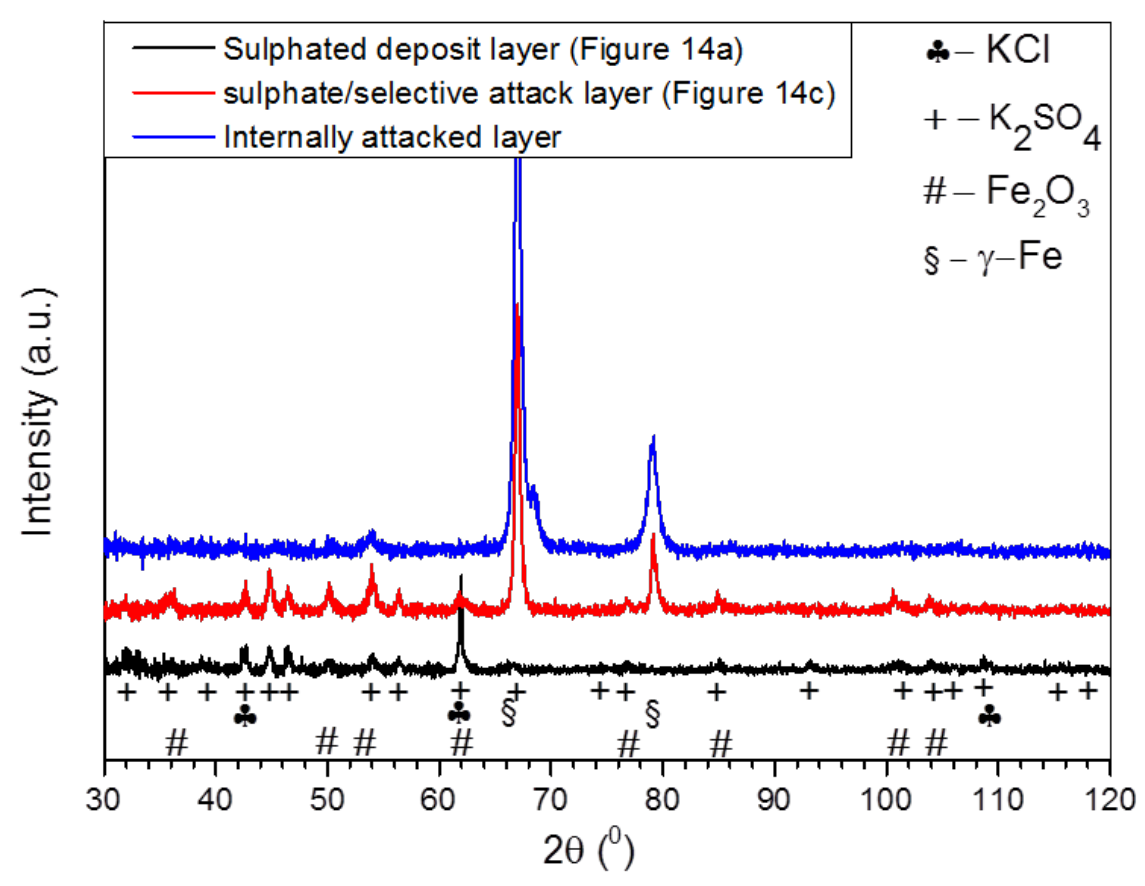

Figure 15. GI-XRD diffractograms showing the predominant crystalline corrosion product phases on the different layers of corrosion product obtained after exposure to condition 2 (flue gas with 13 vol $\% \mathrm{H}_{2} \mathrm{O}$ ) and subsequent stepwise layer removal. 
Corrosion of deposit-free samples exposed to condition 2 resulted in the corrosion products shown in Figure 16. The corrosion product is only very thin and, apparently, it cracked during metallographic preparation of the cross section, hence hindered thorough EDS analysis.
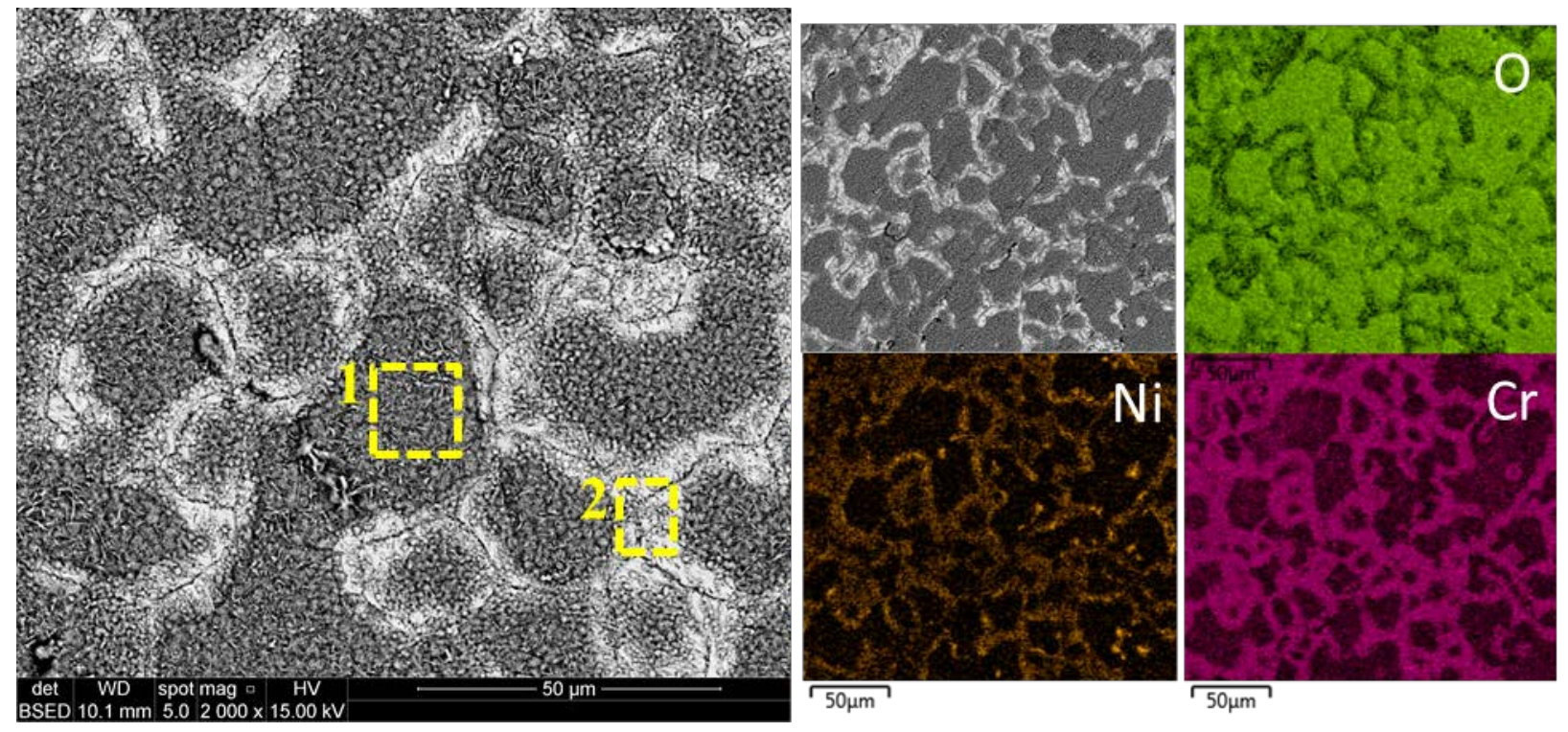

Figure 16. Plan-view and EDS maps of deposit-free sample exposed to condition 2 (flue gas with 13 vol $\% \mathrm{H}_{2} \mathrm{O}$ ). The elemental composition of locations 1 and 2 are given in the supporting information Table S5.

However, the EDS maps on the corrosion product cross section (not shown here) indicate that the corrosion product consists of $\mathrm{Fe}, \mathrm{Cr}$ and $\mathrm{O}$. Sulphur was identified on local positions at the lower region of the corrosion product. It is observed from plan-view investigation (Figure 16) that the interior of the alloy grains is affected by corrosion, whereas regions surrounding the grain boundaries are less attacked. EDS analysis on the different regions show a difference in the concentration of $\mathrm{Cr}, \mathrm{Fe}, \mathrm{Ni}$ and $\mathrm{O}$ (see Table S5, supporting information). Near the grain boundaries, there is an increased concentration of the alloying elements ( $\mathrm{Cr}$ and $\mathrm{Ni}$ ). The only crystalline phases identified were $\mathrm{Fe}_{2} \mathrm{O}_{3}$ (JCPDS card 33-664) and $\gamma$-Fe (JCPDS card 33-397), see Figure 17. The $\gamma$-Fe phase originates from the underlying alloy bulk because of the thin nature of corrosion product layer on the deposit-free sample. 


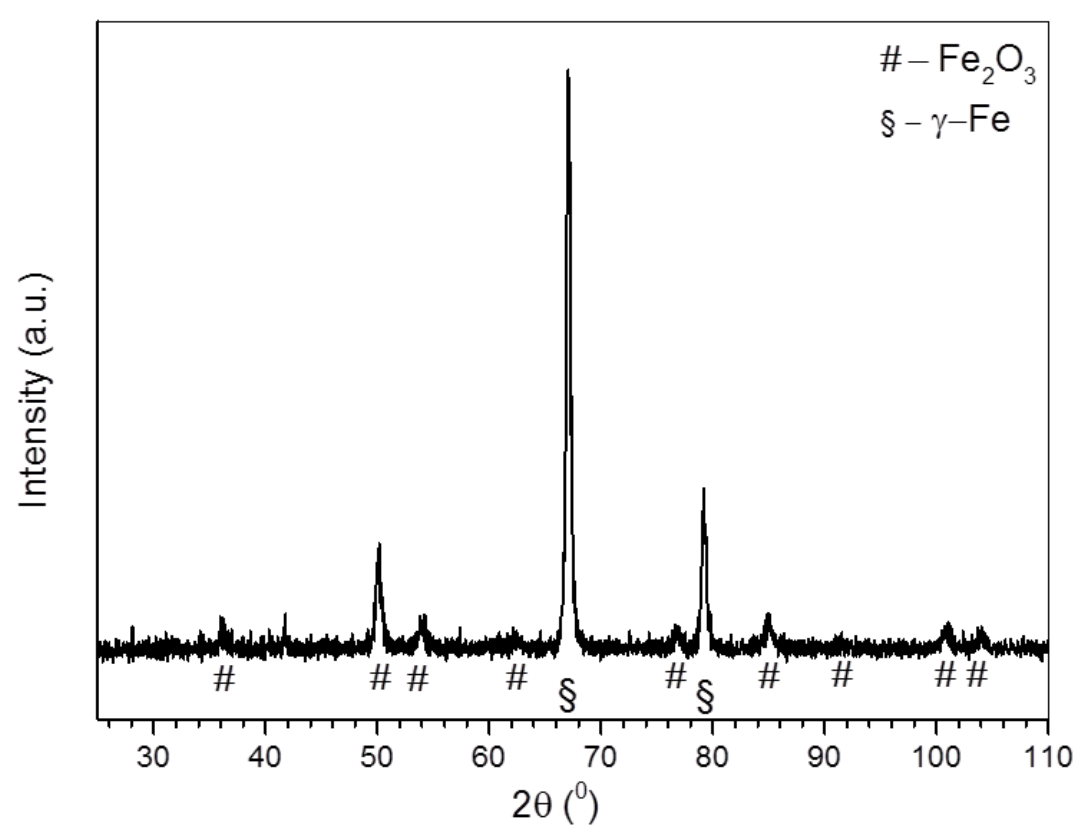

Figure 17. GI-XRD diffractogram showing the predominant crystalline corrosion product phase(s) on the deposit-free sample exposed to condition 2.

\subsection{Thickness of corrosion product layers}

The thicknesses of the different corrosion product layers on the various samples after exposure to the different conditions was measured on more than 20 positions for each sample. Measurement of layer 3 involved both regions where internal /grain boundary attack have occurred. The box charts in Figure 18 shows the statistical distribution of the corrosion product thicknesses. The mean of the measured thickness are represented by the dots inside each box. The standard deviation from the mean is denoted by the two horizontal edges of the box. The 'error' bars above and below the box depict the maximum and minimum measured thicknesses, while the position of $50 \%$ of the measured values is shown by the horizontal line inside each box.

The thickness of corrosion product layers after exposure to the reference condition [44] is observed to exhibit the highest degree of variation. However, for layer 1 (Figure 18a), the mean thickness obtained after exposure to condition 1 and the reference conditions was relatively similar ( $31.1 \pm 8.5 \mu \mathrm{m}$ and 36.3 $\pm 12.6 \mu \mathrm{m}$, respectively), despite the difference in exposure time. A similar trend is observed for layer 2 of corrosion product (Figure 18b): $20.7 \pm 5.9 \mu \mathrm{m}$ and $19.2 \pm 10.0 \mu \mathrm{m}$ for condition 1 and the reference exposure, respectively. 

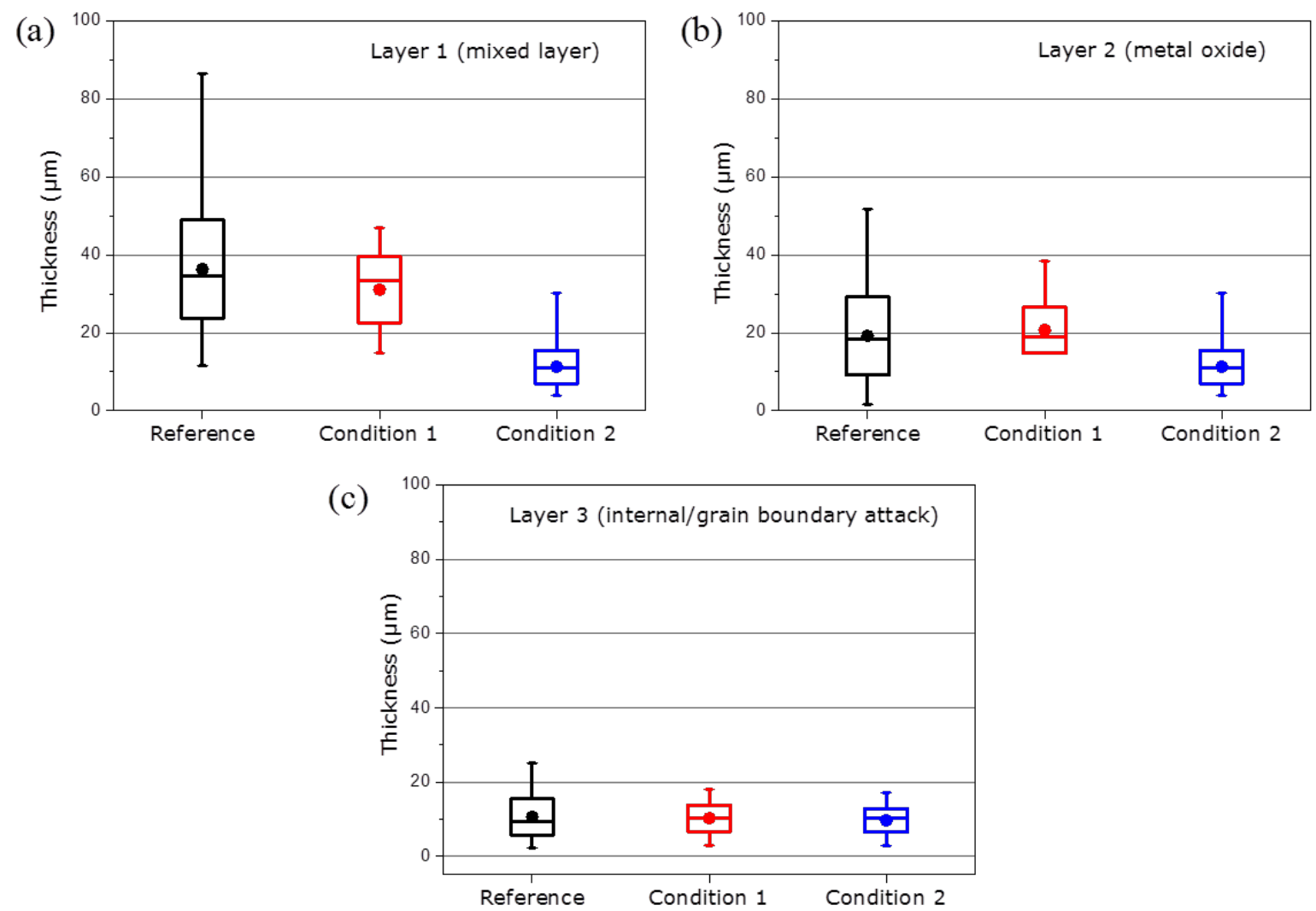

Figure 18. Thicknesses of the resulting corrosion products after exposure to the different conditions. The maximum and minimum thicknesses are represented by the marks above and below each box. Round dots in each box represents the mean thickness. The standard deviation from the mean is represented by the horizontal edges of the box. Location of $50 \%$ of the distribution is depicted by the horizontal bar in each box. At least, 20 positions on the exposed samples were measured to obtain the thickness plot.

Exposure to condition 2 (with 13 vol\% $\mathrm{H}_{2} \mathrm{O}$ in the flue gas) showed relatively lower values of the mean thickness (11.3 $\pm 4.2 \mu \mathrm{m}$ and $10.3 \pm 5.3 \mu \mathrm{m}$ for layer 1 and layer 2 , respectively). It is observed that the thickness of the internal/grain boundary attack regions depended neither on the exposure time, nor the amount of $\mathrm{H}_{2} \mathrm{O}$ vapour in the flue gas (cf. Figure 18c). The average thickness values of these regions from the reference exposure, condition 1 and condition 2 were; $10.6 \pm 4.9 \mu \mathrm{m}, 10.2 \pm 3.6 \mu \mathrm{m}$ and $9.7 \pm$ $3.2 \mu \mathrm{m}$, respectively.

In Figure 19, a schematic summary of the corrosion products after exposure of deposit coated samples to the different conditions is presented. 
(a)

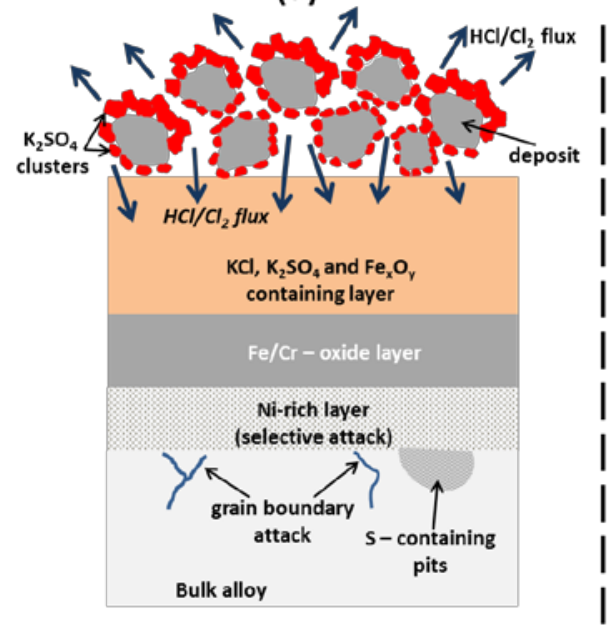

Reference: 3 vol. $\% \mathrm{H}_{2} \mathrm{O}, 168 \mathrm{~h}$ (b)

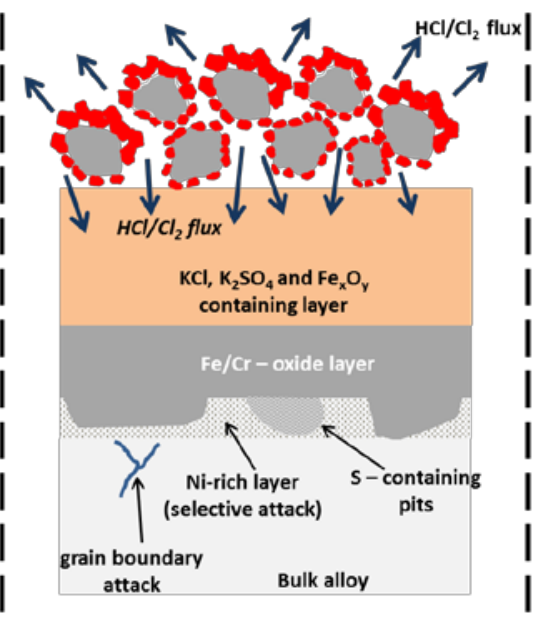

Condition 1: 3 vol. $\% \mathrm{H}_{2} \mathrm{O}, 72 \mathrm{~h}$ (c)

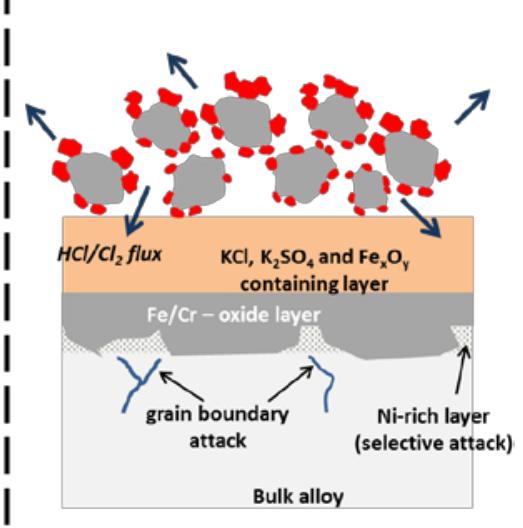

Condition 2: 13 vol. $\% \mathrm{H}_{2} \mathrm{O}, 72 \mathrm{~h}$

Figure 19. Schematic representation of the resulting corrosion products on deposit coated samples from the exposures under the reference condition (a), condition 1 (b) and condition 2 (c).

\section{Discussion}

\subsection{Effect of the exposure time}

High temperature corrosion of superheater materials under biomass-firing conditions is complex. This can be attributed to the interplay between the various corrosive species present. However, the long-term (168 hours) exposure of the investigated material (TP 347H FG) under laboratory conditions simulating biomass-firing indicated that the prominent corrosion mechanisms involve chlorination-oxidation and sulphidation [44]. Under such conditions (which serve as the reference condition in the current study), sulphation of the initial deposit, direct reaction of the deposit with the preformed oxide on the alloy as well as direct attack of the flue gas on the alloy, were suggested as possible pathways to initiate the corrosion attack. Thorough comparison of the morphology of corrosion products formed after both 168 $\mathrm{h}$ (reference, Figure S1 in supporting information) and $72 \mathrm{~h}$ (condition 1, Figure 2) of exposure to such conditions showed the formation of three layers of corrosion products. The only pronounced difference between the two exposure times is the clear establishment of the Ni-rich porous region in layer 3 as a result of the extended exposure time of $168 \mathrm{~h}$. Such difference suggests that the action of $\mathrm{Cl}$ species in selectively extracting 'less noble' alloying elements (Fe and $\mathrm{Cr}$ [44]) is time dependent and therefore a propagating step and not an initiation step. As clearly observed from the EDS maps of the corrosion products after $72 \mathrm{~h}$ of exposure (Figure 3), layer 3 has not fully developed into a Ni-rich porous layer. Instead, $\mathrm{Cr}$ is observed in addition to $\mathrm{Ni}$ where such porous regions have started to form. The time dependent evolution of the $\mathrm{Ni}$ rich porous layer due to selective attack by $\mathrm{Cl}$ is supported by the clear 
development of this layer after a longer (field) exposure (3462 h) of the investigated material in a straw fired plant [47].

The exposure time marginally influences the thickness of the corrosion products layers (for the flue gas containing $3 \mathrm{vol} \% \mathrm{H}_{2} \mathrm{O}$ ) as the average measured thicknesses of the three layers are in close agreement (Figure 18). However, the maximum thickness of the corrosion product layers is observed to clearly increase with time. The observed thickness of corrosion product after $72 \mathrm{~h}$ of exposure is in agreement with that observed in a similar study[13]. Based on the slow increase in corrosion product thickness recorded for the investigated material even after 150 days of exposure to similar conditions [19], the similarity in average thickness of corrosion products after 72 and $168 \mathrm{~h}$ is confirmed. This observation has two implications:

- The resulting corrosion products after a given time impose some degree of resistance to transport of species to/from the corrosion front.

- The catastrophic corrosive species $(\mathrm{KCl})$ become consumed in the corrosion process after a given period. Subsequently, the flue gas components and the less corrosive corrosion product (for example, potassium sulphate) will result in attack leading to a relatively slow increase in the thickness of corrosion products. This is one of the constraints of such a laboratory set-up because in the real plant; the deposit is constantly being replenished.

\subsection{Effect of $\mathrm{H}_{2} \mathrm{O}$ vapour concentration in the flue gas}

Although from a generalized perceptive, three layers of corrosion products were observed regardless of the concentration of $\mathrm{H}_{2} \mathrm{O}$ vapour in the flue gas, the morphology, thickness and distribution of the corrosion products varied significantly as a function of $\mathrm{H}_{2} \mathrm{O}$ vapour concentration (see Figures 2, 3, 11 and 12). The synergistic/antagonistic behaviour of $\mathrm{H}_{2} \mathrm{O}$ vapour on high temperature oxidation has been effectively reviewed in the literature [36,38]. It has been suggested that $\mathrm{H}_{2} \mathrm{O}$ vapour can influence the corrosion process via several mechanisms, for example:

(a) Formation of volatile metal-oxyhydroxide species consequently leading to the formation of less protective Fe-rich oxides [14,28-30,37,48].

(b) Enhanced growth of the oxide scale due to faster transport of $\mathrm{H}^{+} / \mathrm{OH}^{-}$in the scale $[31,35]$.

(c) Assisting the internal oxidation of $\mathrm{Cr}$ and as a result aiding the outward growth of Fe-rich oxide [31,33].

(d) Competitive $\mathrm{H}_{2} \mathrm{O} / \mathrm{O}_{2}$ adsorption at the scale-gas and scale-metal interfaces [31,36,49]. 
A general consequence of the above mechanisms is an increase in the growth of an external Fe-rich corrosion product. Since the concentration of other gas species $\left(\mathrm{SO}_{2}, \mathrm{CO}_{2}, \mathrm{O}_{2}\right.$ and $\left.\mathrm{HCl}\right)$ in the flue gas were kept constant in the different exposures, $\mathrm{H}_{2} \mathrm{O}$ vapour is observed to influence high temperature corrosion of deposit-free samples in the present investigation. A similar effect of $\mathrm{H}_{2} \mathrm{O}$ in dominating the oxide formation mechanism was reported for studies under oxyfuel gaseous conditions [50]. Plan-view investigations on samples exposed to a flue gas containing $13 \mathrm{vol} \% \mathrm{H}_{2} \mathrm{O}$ (Figure 16) show that regions at the grain boundaries are attacked to a lesser extent relative to the alloy grain interior. This observation hence supports the fact that the continuous supply of Cr from faster transport paths (grain boundaries) is able to sustain the formation of a more protective oxide. Insufficient supply of Cr from the bulk alloy to the interior of grains in the subsurface caused the formation of thicker Fe-rich corrosion products as the outer oxide probably according to mechanism (a) above. The corrosion products on deposit-free samples exposed to a flue gas with $3 \mathrm{vol} \% \mathrm{H}_{2} \mathrm{O}$ content did not display a similar trend. In fact very little sign of grain boundary protectiveness is observed on the regions with fine morphological features (see Figure 9). Under such conditions, $\frac{p_{\mathrm{H}_{2} \mathrm{O}}}{p_{\mathrm{O}_{2}}}<1$ holds and, hence, $\mathrm{H}_{2} \mathrm{O}$ vapour would have a reduced effect on corrosion. However, either $\mathrm{Cl}$ or $\mathrm{SO}_{2}$ from the flue gas could have caused an accelerated attack to justify the thick and coarse corrosion product morphology observed on some regions of the exposed samples (Figure 9a). Considering that $\mathrm{HCl}$ dissociates into $\mathrm{Cl}_{2}$ according reaction (1), it is expected that in order to sustain equilibrium, an increase in $p_{\mathrm{H}_{2} \mathrm{O}}$ will cause a decrease in $p_{\mathrm{Cl}_{2}}$. An opposite effect will be observed at low $p_{\mathrm{H}_{2} \mathrm{O}}$ which may explain the resulting thick and coarse corrosion products on some regions of the exposed sample due to enhanced attack by $\mathrm{Cl}_{2}$.

$$
2 \mathrm{HCl}(\mathrm{g})+\frac{1}{2} \mathrm{O}_{2}(\mathrm{~g}) \rightleftharpoons \mathrm{Cl}_{2}(\mathrm{~g})+\mathrm{H}_{2} \mathrm{O}(\mathrm{g})
$$

In the present investigation of the effect of $\mathrm{H}_{2} \mathrm{O}$ vapour in the presence of a $\mathrm{KCl}$ deposit, a decrease in the corrosion product thickness is observed with increasing $\mathrm{H}_{2} \mathrm{O}$ vapour concentration. Additionally, no clear increase of the corrosion product porosity/densification can be observed after exposure to conditions 1 and 2 (see Figures 2 and 11). Justifiably the above listed mechanisms ( $\mathrm{a}-\mathrm{d}$ ) cannot explain the $\mathrm{H}_{2} \mathrm{O}$ vapour effect observed on deposit coated samples since they were solely developed based on a gas-metal interaction. However, it has been suggested that in the presence of solid corrosive species $(\mathrm{KCl}, \mathrm{NaCl})$ [41-43,51], the synergistic corrosion accelerating effect of $\mathrm{H}_{2} \mathrm{O}$ vapour originates from the higher thermodynamic favourability of reaction (2) compared to reaction (3).

$$
\begin{gathered}
\mathrm{xNCl}_{(\mathrm{s})}+\mathrm{M}_{\mathrm{x}} \mathrm{O}_{\mathrm{y}}+\mathrm{H}_{2} \mathrm{O} \rightleftharpoons \mathrm{N}_{\mathrm{x}} \mathrm{M}_{\mathrm{x}} \mathrm{O}_{(\mathrm{y}+1)}+\mathrm{xHCl} \\
\mathrm{xNCl}_{(\mathrm{s})}+\mathrm{M}_{\mathrm{x}} \mathrm{O}_{\mathrm{y}}+\frac{1}{x} \mathrm{O}_{2} \rightleftharpoons \mathrm{N}_{\mathrm{x}} \mathrm{M}_{\mathrm{x}} \mathrm{O}_{\left(\mathrm{y}+\frac{2}{x}\right)}+\mathrm{Cl}_{x}
\end{gathered}
$$




$$
(\mathrm{N}=\{\mathrm{K}, \mathrm{Na}\}, \mathrm{M}=\{\mathrm{Fe}, \mathrm{Cr}\}, \text { and } \mathrm{x}, \mathrm{y} \text { are integers }) .
$$

The $\mathrm{HCl}$ released from reaction (2) is able to chlorinate the alloying elements resulting in the formation of volatile metal chlorides (reaction 4). Oxidation of these species yields a porous oxide and also the regeneration of $\mathrm{HCl}$ (reaction 5) which partly reinitiates the chlorination reaction in a cyclic manner.

$$
\begin{gathered}
\mathrm{M}+\mathrm{xHCl} \rightleftharpoons \mathrm{MCl}_{\mathrm{x}}+\frac{\mathrm{x}}{2} \mathrm{H}_{2} \\
\mathrm{MCl}_{\mathrm{x}}+\mathrm{yH}_{2} \mathrm{O} \rightleftharpoons \mathrm{M}_{\mathrm{x}} \mathrm{O}_{\mathrm{y}}+(2 \mathrm{y}) \mathrm{HCl}
\end{gathered}
$$

The present results reveal that $\mathrm{H}_{2} \mathrm{O}$ vapour does not increase corrosion attack on the investigated alloy under the present conditions. Similar investigations of high temperature corrosion of austenitic steel AISI 304 L [38], alloy 625 [40], ferritic 10CrMo910 steel [40] and FeCrAl alloy [34] show a decrease in corrosion with an increase in $\mathrm{H}_{2} \mathrm{O}$ vapour concentration. The densification of the resulting corrosion product or ability of the $\mathrm{HCl}$ from reaction (2) to exit from the corrosion system has been suggested to compensate for the observed trend. However, in the present investigation where the sulphation of the deposit particles also contributes to an increase in the corrosive species ( $\mathrm{HCl}, \mathrm{K}_{2} \mathrm{SO}_{4}$ ), it is meaningful to consider the possible effect of $\mathrm{H}_{2} \mathrm{O}$ vapour on the flue gas-deposit interactions.

With the presence of $\mathrm{SO}_{2}$ in the flue gas, sulphation of the initial deposit ( $\mathrm{KCl}$ particles) is expected to proceed in a mechanism similar to the Hargreaves process [52] (reaction 6) in which $\mathrm{HCl}$ is released in the flue gas.

$$
2 \mathrm{KCl}(\mathrm{s})+\mathrm{SO}_{2}(\mathrm{~g})+\frac{1}{2} \mathrm{O}_{2}(\mathrm{~g})+\mathrm{H}_{2} \mathrm{O} \rightleftharpoons \mathrm{K}_{2} \mathrm{SO}_{4}(\mathrm{~s})+2 \mathrm{HCl}(\mathrm{g})
$$

Comparison of the cross-sections in Figure 2 for condition 1, and Figure 11 for condition 2 reveal a decrease in thickness of layer 1 when specimens are exposed to the $13 \mathrm{vol} \% \mathrm{H}_{2} \mathrm{O}$ containing flue gas. The degree of $\mathrm{K}_{2} \mathrm{SO}_{4}$ accumulation around the deposit particles is also observed to be significantly reduced with 13 vol \% (Figure 13), instead of 3 vol \% (Figure 4) $\mathrm{H}_{2} \mathrm{O}$. These observations suggest that more of the $\mathrm{KCl}$ deposit is sulphated (and therefore more $\mathrm{HCl}$ is generated) in the flue gas with lower concentration of $\mathrm{H}_{2} \mathrm{O}$ vapour. A corresponding small increase in thickness of the metal oxide containing layer of the corrosion product - layer 2 (Figure 18) also suggests that a significant proportion of the released $\mathrm{HCl}$ from the sulphation process (reaction 5) has contributed to corrosion. The generated $\mathrm{HCl}$ can dissociate into $\mathrm{Cl}_{2}$ (reaction 1) which can migrate to the corrosion front and induce chlorination of thermodynamically favourable alloying elements (reaction 7) [53-56]. Similarly, electrochemical migration of adsorbed $\mathrm{Cl}$ ions to the corrosion front $[18,34,57]$ will give rise to chlorination of the most 
favourable alloying element. The resultant volatile metal chlorides are transported away from the corrosion front and subsequently oxidized to release $\mathrm{Cl}$ (reaction 9), which partly migrates back to the corrosion front and continues the process in a cyclic mechanism (the so-called chlorine cycle). The selective depletion of $\mathrm{Fe}$ and $\mathrm{Cr}$ are explained by the thermodynamically favoured chlorination of these elements relative to $\mathrm{Ni}[21,44,55,56]$, hence suggesting a $\mathrm{Cl}$ assisted type of corrosion attack.

$$
\begin{aligned}
\mathrm{M}(\mathrm{s})+\mathrm{xCl} & \rightleftharpoons \mathrm{MCl}_{\mathrm{x}}(\mathrm{s}) \\
\mathrm{MCl}_{\mathrm{x}}(\mathrm{s}) & \rightleftharpoons \mathrm{MCl}_{\mathrm{x}}(\mathrm{g}) \\
\mathrm{yMCl}_{\mathrm{x}}(\mathrm{g})+\frac{\mathrm{z}}{2} \mathrm{O}_{2}(\mathrm{~g}) & \rightleftharpoons \mathrm{M}_{\mathrm{y}} \mathrm{O}_{\mathrm{z}}(\mathrm{s})+\mathrm{yCl} \mathrm{x}_{\mathrm{x}}(\mathrm{g})
\end{aligned}
$$

Owing to the porous morphology of the oxides converted from metal chlorides, it is reasonable that enhanced migration of corrosive species occurs. This explains the accumulation of $\mathrm{S}$ at the corrosion front after exposure of the deposit-coated samples to the different conditions (see Figures 3 and 12). It is suggested that sulphidation may proceed due to enhanced transportation of $\mathrm{SO}_{2}$ across the porous oxide formed as a result of the cyclic $\mathrm{Cl}$ attack.

With respect to the kinetics of reaction 6 , reported results on the effect of $\mathrm{H}_{2} \mathrm{O}$ vapour concentration are somewhat inconclusive. While model predictions and some experimental results suggest an insignificant effect of $\mathrm{H}_{2} \mathrm{O}$ concentration on the heterogeneous sulphation of alkali chlorides ( $\left.\mathrm{KCl} / \mathrm{NaCl}\right)$ [58-62], thorough analysis of some experimental results reported in literature reveal an interesting trend. At constant $\mathrm{SO}_{2}$ and $\mathrm{O}_{2}$ concentrations, a potential maximum in the reaction kinetics is observed in the sulphation of $\mathrm{NaCl}\left(\right.$ at $600{ }^{\circ} \mathrm{C}$ ) [61] when the $\mathrm{H}_{2} \mathrm{O}$ vapour concentration approaches $10 \mathrm{vol} \%$. Above this concentration, a decrease in conversion rate is observed. The rate determining steps in the heterogeneous sulphation of deposit particles will involve adsorption of $\mathrm{SO}_{2}, \mathrm{O}_{2}$ and $\mathrm{H}_{2} \mathrm{O}$ on the surface of the deposit [61-63]. Hence the present authors suggest that a competitive adsorption on active sites of the deposit particle may influence the kinetics of the process, and by extension, the rate with which $\mathrm{HCl}$ is released. A similar mechanism based on preferential adsorption of $\mathrm{H}_{2} \mathrm{O}$ in $\mathrm{CO}_{2}$ containing gases has been used to explain reduced carburisation [64]. Even though $\mathrm{H}_{2} \mathrm{O}$ facilitates the formation of the intermediate specie $\left(\mathrm{H}_{2} \mathrm{SO}_{4}\right)$ in the sulphation process via a proton transfer to $\mathrm{SO}_{3}$ [63], it is possible that above a certain concentration, the adsorbed $\mathrm{H}_{2} \mathrm{O}$ species exert an inhibiting influence instead. Alternatively, it is probable that with increased active site coverage by adsorbed $\mathrm{H}_{2} \mathrm{O}$ species, the available sites for adsorption of other species such as $\mathrm{SO}_{2}$ become restricted (steric hindrance) and accordingly a decrease in sulphation rate is observed. Although the limits of experimental error in previous experimental investigations [59,61] is unknown, results indicate that such phenomena will likely occur above a critical $\mathrm{H}_{2} \mathrm{O}$ vapour concentration around $10 \mathrm{vol} \%$. Indeed proper studies in this 
regard are needed to clarify the effect of $\mathrm{H}_{2} \mathrm{O}$ vapour on the sulphation kinetics of alkali chlorides. Nonetheless, the observed trend with an increase in flue gas $\mathrm{H}_{2} \mathrm{O}$ content in the present investigation can be explained by the above suggestions.

\section{Conclusions}

Laboratory-scale high temperature exposures have been carried out with a view to investigate the effect of exposure time and $\mathrm{H}_{2} \mathrm{O}$ vapour content on the corrosion of TP $347 \mathrm{H}$ FG under conditions mimicking biomass firing. Comprehensive characterization of the resulting corrosion products using SEM, EDS and XRD was achieved by both cross-sectional and plan-view investigations after mechanical removal of the corrosion product layers.

Corrosion products generally contain three layers irrespective of the exposure time or condition. However, it is shown that the development of the Ni-rich porous layer due to selective attack by $\mathrm{Cl}$ is observed with longer exposure times.

With respect to the influence of $\mathrm{H}_{2} \mathrm{O}$ vapour, an antagonistic effect was observed on the corrosion process upon an increase in the amount of $\mathrm{H}_{2} \mathrm{O}$ vapour in the flue gas. The observed corrosion morphologies on samples coated with a $\mathrm{KCl}$ deposit could not be explained based on classical $\mathrm{H}_{2} \mathrm{O}$ vapour corrosion accelerating mechanisms. Such accelerating mechanism was only observed on deposit-free samples exposed to flue gas with $13 \mathrm{vol} \% \mathrm{H}_{2} \mathrm{O}$ vapour.

Based on previous experimental results in literature and results from the current investigation, it is suggested that above a critical $\mathrm{H}_{2} \mathrm{O}$ vapour concentration, competition for active adsorption sites will lead to a decrease in the sulphation of the initial deposits as well as $\mathrm{HCl}$ generation, and consequently a lower extent of corrosion.

\section{AUTHOR INFORMATION}

\section{Corresponding Author}

* Phone: +45 50185680, Email: sunoko@mek.dtu.dk

\section{ACKNOWLEDGEMENT}

This work is part of the Danish Strategic Research Centre, Power Generation from Renewable Energy (GREEN). The authors acknowledge funding from the Danish council for Strategic Research. 


\section{REFERENCES}

[1] H.P. Nielsen, F.J. Frandsen, K. Dam-Johansen, L.L. Baxter, The implications of chlorineassociated corrosion on the operation of biomass-fired boilers, Prog. Energy Combust. Sci. 26 (2000) 283-298.

[2] M. Montgomery, B. Sander, O.H. Larsen, Biomass firing: Danish experiences, Energy Mater. 1 (2006) 17-19.

[3] F.J. Frandsen, Ash Formation, Deposition and Corrosion when Utilizing Straw for Heat and Power Production, Dr. Techn. Thesis, Department of Chemical and Biochemical Engineering, Technical Univeristy of Denmark. ISBN: 9788792481405, Kongens Lyngby, 2011.

[4] C. Liu, J.A. Little, P.J. Henderson, P. Ljung, Corrosion of TP347H FG stainless steel in a biomass fired PF utility boiler, J. Mater. Sci. 36 (2001) 1015-1026.

[5] K.A. Christensen, M. Stenholm, H. Livbjerg, The formation of submicron aerosol particles, $\mathrm{HCl}$ and SO2 in straw-fired boilers, J. Aerosol Sci. 29 (1998) 421-444.

[6] R.A. Antunes, M.C.L. de Oliveira, Corrosion in biomass combustion: A materials selection analysis and its interaction with corrosion mechanisms and mitigation strategies, Corros. Sci. 76 (2013) 6-26.

[7] S.C. Cha, M. Spiegel, Local reactions of $\mathrm{KCl}$ particles with iron, nickel and chromium surfaces, Mater. Corros. 57 (2006) 159-164.

[8] C. Pettersson, J. Pettersson, H. Asteman, J.-E. Svensson, L.-G. Johansson, KCl-induced high temperature corrosion of the austenitic $\mathrm{Fe}-\mathrm{Cr}-\mathrm{Ni}$ alloys $304 \mathrm{~L}$ and Sanicro 28 at $600^{\circ} \mathrm{C}$, Corros. Sci. 48 (2006) 1368-1378.

[9] J. Pettersson, H. Asteman, J.-E. Svensson, L.-G. Johansson, KCl Induced Corrosion of a 304type Austenitic Stainless Steel at $600^{\circ} \mathrm{C}$; The Role of Potassium, Oxid. Met. 64 (2005) 23-41.

[10] J. Pettersson, J.-E. Svensson, L.-G. Johansson, KCl-Induced Corrosion of a 304-type Austenitic Stainless Steel in $\mathrm{O} 2$ and in $\mathrm{O} 2+\mathrm{H} 2 \mathrm{O}$ Environment: The Influence of Temperature, Oxid. Met. 72 (2009) 159-177.

[11] S. Sroda, S. Tuurna, Laboratory scale tests on corrosion behavior of boiler materials in simulated combustion atmospheres (EU Project - OPTICORR), Mater. Corros. 57 (2006) 244-251.

[12] J. Sui, J. Lehmusto, M. Bergelin, M. Hupa, The Onset of Potassium Chloride Induced High 
Temperature Corrosion: A Novel Experimental Approach, Oxid. Met. 82 (2014) 437-456.

[13] S.C. Van Lith, F.J. Frandsen, M. Montgomery, T. Vilhelmsen, S.A. Jensen, Lab-scale Investigation of Deposit-induced Chlorine Corrosion of Superheater Materials under Simulated Biomass-firing Conditions. Part 1: Exposure at $560^{\circ} \mathrm{C}$, Energy \& Fuels. 59 (2009) 3457-3468.

[14] T. Jonsson, J. Froitzheim, J. Pettersson, J.-E. Svensson, L.-G. Johansson, M. Halvarsson, The Influence of $\mathrm{KCl}$ on the Corrosion of an Austenitic Stainless Steel (304L) in Oxidizing Humid Conditions at $600{ }^{\circ} \mathrm{C}$ : A Microstructural Study, Oxid. Met. 72 (2009) 213-239.

[15] T. Jonsson, N. Folkeson, J.-E. Svensson, L.-G. Johansson, M. Halvarsson, An ESEM in situ investigation of initial stages of the $\mathrm{KCl}$ induced high temperature corrosion of a $\mathrm{Fe}-2.25 \mathrm{Cr}-$ 1 Mo steel at $400^{\circ} \mathrm{C}$, Corros. Sci. 53 (2011) 2233-2246.

[16] N. Folkeson, T. Jonsson, M. Halvarsson, L.-G. Johansson, J.-E. Svensson, The influence of small amounts of $\mathrm{KCl}(\mathrm{s})$ on the high temperature corrosion of a Fe-2.25Cr-1Mo steel at 400 and $500^{\circ} \mathrm{C}$, Mater. Corros. 62 (2011) 606-615.

[17] C. Proff, T. Jonsson, C. Pettersson, J.-E. Svensson, L.-G. Johansson, M. Halvarsson, Microstructural investigation of the KCl-induced corrosion of the austenitic alloy Sanicro 28 (35Fe27Cr31Ni) at $600^{\circ} \mathrm{C}$, Mater. High Temp. 26 (2009) 113-125.

[18] T. Jonsson, N. Folkeson, M. Halvarsson, J.-E. Svensson, L.-G. Johansson, Microstructural Investigation of the HCl-Induced Corrosion of the Austenitic Alloy 310S (52Fe26Cr19Ni) at 500 ${ }^{\circ} \mathrm{C}$, Oxid. Met. 81 (2014) 575-596.

[19] H.P. Nielsen, F.J. Frandsen, K. Dam-Johansen, Lab-Scale Investigations of High-Temperature Corrosion Phenomena in Straw-Fired Boilers, Energy \& Fuels. 13 (1999) 1114-1121.

[20] D.P. Miller, H.H. Krause, J. Zupan, K.W. Boyd, Corrosive Effects of Various Salt Mixtures Under Combustion Gas Atmospheres, Corrosion. 28 (1972) 222-225.

[21] A. Zahs, M. Spiegel, H. Grabke, The influence of alloying elements on the chlorine-induced high temperature corrosion of Fe-Cr alloys in oxidizing atmospheres, Mater. Corros. 50 (1999) 561-578.

[22] N. Folkeson, J. Pettersson, C. Pettersson, L.G. Johansson, E. Skog, B.Å. Andersson, S. Enestam, J. Tuiremo, A. Jonasson, B. Heikne, J.E. Svensson, Fireside Corrosion of Stainless and Low Alloyed Steels in a Waste-Fired CFB Boiler; The Effect of Adding Sulphur to the Fuel, Mater. Sci. Forum. 595-598 (2008) 289-297. 
[23] M. Paneru, G. Stein-Brzozowska, J. Maier, G. Scheffknecht, Corrosion Mechanism of Alloy 310 Austenitic Steel beneath NaCl Deposit under Varying SO2 Concentrations in an Oxy-fuel Combustion Atmosphere, Energy \& Fuels. 27 (2013) 5699-5705.

[24] J. Pettersson, J.E. Svensson, L.G. Johansson, Alkali Induced Corrosion of 304-Type Austenitic Stainless Steel at $600^{\circ} \mathrm{C}$; Comparison between $\mathrm{KCl}, \mathrm{K} 2 \mathrm{CO} 3$ and K2SO4, Mater. Sci. Forum. 595-598 (2008) 367-375.

[25] S. Karlsson, T. Jonsson, J. Hall, J.-E. Svensson, J. Liske, Mitigation of Fireside Corrosion of Stainless Steel in Power Plants: A Laboratory Study of the Influences of SO2 and $\mathrm{KCl}$ on Initial Stages of Corrosion, Energy \& Fuels. 28 (2014) 3102-3109.

[26] S. Karlsson, J. Pettersson, J.E. Svensson, L.G. Johansson, KCl-Induced High Temperature Corrosion of the Austenitic Stainless Steel 304L - The Influence of SO2, Mater. Sci. Forum. 696 (2011) 224-229.

[27] A. Järdnäs, J.-E. Svensson, L.-G. Johansson, Influence of SO2 on the Oxidation of 304L Steel in $\mathrm{O} 2+40 \% \mathrm{H} 2 \mathrm{O}$ at $600{ }^{\circ} \mathrm{C}$, Oxid. Met. 69 (2008) 249-263.

[28] H. Asteman, J. Svensson, M. Norell, L. Johansson, Influence of Water Vapor and Flow Rate on the High-Temperature Oxidation of 304L ; Effect of Chromium Oxide Hydroxide Evaporation, Oxid. Met. 54 (2000) 11-26.

[29] H. Asteman, J.-E. Svensson, L.-G. Johansson, Oxidation of 310 steel in $\mathrm{H} 2 \mathrm{O} / \mathrm{O} 2$ mixtures at 600 ${ }^{\circ} \mathrm{C}$ : the effect of water-vapour-enhanced chromium evaporation, Corros. Sci. 44 (2002) 26352649.

[30] H. Asteman, J.-E. Svensson, L.-G. Johansson, M. Norell, Indication of Chromium Oxide Hydroxide Evaporation During Oxidation of 304L at $873 \mathrm{~K}$ in the Presence of $10 \%$ Water Vapor, Oxid. Met. 52 (1999) 95-111.

[31] E. Essuman, G.H. Meier, J. Żurek, M. Hänsel, L. Singheiser, W.J. Quadakkers, Enhanced internal oxidation as trigger for breakaway oxidation of $\mathrm{Fe}-\mathrm{Cr}$ alloys in gases containing water vapor, Scr. Mater. 57 (2007) 845-848.

[32] A.N. Hansson, H. Danielsen, F.B. Grumsen, M. Montgomery, Microstructural investigation of the oxide formed on TP 347H FG during long-term steam oxidation, Mater. Corros. 61 (2009) $665-675$.

[33] A.N. Hansson, K. Pantleon, F.B. Grumsen, M.A.J. Somers, Microstructure Evolution During Steam Oxidation of a Nb Stabilized Austenitic Stainless Steel, Oxid. Met. 73 (2009) 289-309. 
[34] N. Israelsson, K. Hellström, J.-E. Svensson, L.-G. Johansson, KCl-Induced Corrosion of the FeCrAl Alloy Kanthal ${ }^{\circledR}$ AF at $600{ }^{\circ} \mathrm{C}$ and the Effect of H2O, Oxid. Met. 83 (2015) 1-27.

[35] H. Nickel, Y. Wouters, M. Thiele, W.J. Quadakkers, The effect of water vapor on the oxidation behavior of 9\%Cr steels in simulated combustion gases, Fresenius. J. Anal. Chem. 361 (1998) 540-544.

[36] D.J. Young, Effects of Water Vapour on Oxidation, in: Corros. Ser., Elsevier, 2008: pp. 455495.

[37] T. Jonsson, B. Pujilaksono, S. Hallström, J. Ågren, J.-E. Svensson, L.-G. Johansson, M. Halvarsson, An ESEM in situ investigation of the influence of $\mathrm{H} 2 \mathrm{O}$ on iron oxidation at $500^{\circ} \mathrm{C}$, Corros. Sci. 51 (2009) 1914-1924.

[38] S.R.J. Saunders, M. Monteiro, F. Rizzo, The oxidation behaviour of metals and alloys at high temperatures in atmospheres containing water vapour: A review, Prog. Mater. Sci. 53 (2008) 775-837.

[39] J. Lehmusto, B.-J. Skrifvars, P. Yrjas, M. Hupa, Comparison of potassium chloride and potassium carbonate with respect to their tendency to cause high temperature corrosion of stainless 304L steel, Fuel Process. Technol. 105 (2013) 98-105.

[40] J. Lehmusto, P. Yrjas, B.-J. Skrifvars, M. Hupa, High temperature corrosion of superheater steels by KCl and K2CO3 under dry and wet conditions, Fuel Process. Technol. 104 (2012) 253264.

[41] F. Wang, Y. Shu, Influence of Cr Content on the Corrosion of Fe - Cr Alloys : The Synergistic Effect of NaCl and Water Vapor, Oxid. Met. 59 (2003) 201-214.

[42] Y. Shu, F. Wang, W. Wu, Synergistic Effect of NaCl and Water Vapor on the Corrosion of 1Cr$11 \mathrm{Ni}-2 \mathrm{~W}-2 \mathrm{Mo}-\mathrm{V}$ Steel at 500-700 C, Oxid. Met. 51 (1999) 97-110.

[43] Y. Tang, L. Liu, Y. Li, F. Wang, The Electrochemical Corrosion Mechanisms of Pure Cr with $\mathrm{NaCl}$ Deposit in Water Vapor at 600 C, J. Electrochem. Soc. 158 (2011) C237.

[44] S.C. Okoro, M. Montgomery, F.J. Frandsen, K. Pantleon, High Temperature Corrosion under Laboratory Conditions Simulating Biomass-Firing: A Comprehensive Characterization of Corrosion Products, Energy \& Fuels. 28 (2014) 6447-6458.

[45] H.J. Grabke, D.B. Meadowcroft, eds., A Working Party Report on Guidelines for Methods of Testing and Research in High Temperature Corrosion, European Federation of Corrosion 
Publications, 1995.

[46] K.E. Coleman, N.J. Simms, P.J. Kilgallon, J.E. Oakey, Corrosion in Biomass Combustion Systems, Mater. Sci. Forum. 595-598 (2008) 377-386.

[47] M. Montgomery, A. Karlsson, O.H. Larsen, Field test corrosion experiments in Denmark with biomass fuels. Part 1: Straw-firing, Mater. Corros. 53 (2002) 121-131.

[48] B. Pujilaksono, T. Jonsson, M. Halvarsson, J.-E. Svensson, L.-G. Johansson, Oxidation of iron at $400-600^{\circ} \mathrm{C}$ in dry and wet O2, Corros. Sci. 52 (2010) 1560-1569.

[49] J. Ehlers, D.J. Young, E.J. Smaardijk, A.K. Tyagi, H.J. Penkalla, L. Singheiser, W.J. Quadakkers, Enhanced oxidation of the 9\%Cr steel P91 in water vapour containing environments, Corros. Sci. 48 (2006) 3428-3454.

[50] P. Huczkowski, T. Olszewski, M. Schiek, B. Lutz, G.R. Holcomb, V. Shemet, W. Nowak, G.H. Meier, L. Singheiser, W.J. Quadakkers, Effect of SO 2 on oxidation of metallic materials in CO 2 /H 2 O-rich gases relevant to oxyfuel environments, Mater. Corros. 65 (2014) 121-131.

[51] S.C. Cha, High temperature corrosion of superheater materials below deposited biomass ashes in biomass combusting atmospheres, Corros. Eng. Sci. Technol. 42 (2007) 50-60.

[52] S. Uchida, H. Kamo, H. Kubota, K. Kanaya, Reaction kinetics of formation of hydrochloric acid in municipal refuse incinerators, Ind. Eng. Chem. Process Des. Dev. 22 (1983) 144-149.

[53] S.C. Cha, M. Spiegel, Fundamental Studies on Alkali Chloride Induced Corrosion during Combustion of Biomass, Mater. Sci. Forum. 461-464 (2004) 1055-1062.

[54] H.J. Grabke, E. Reese, M. Spiegel, The effects of chlorides, hydrogen chloride, and sulfur dioxide in the oxidation of steels below deposits, Corros. Sci. 37 (1995) 1023-1043.

[55] R. Bender, M. Schütze, The role of alloying elements in commercial alloys for corrosion resistance in oxidizing-chloridizing atmospheres part I: Literature evaluation and thermodynamic calculations on phase stabilities, Mater. Corros. 54 (2003) 567-586.

[56] R. Bender, M. Schütze, The role of alloying elements in commercial alloys for corrosion resistance in oxidizing-chloridizing atmospheres. Part II: Experimental investigations, Mater. Corros. 54 (2003) 652-686.

[57] N. Folkeson, L.-G. Johansson, J.-E. Svensson, Initial Stages of the HCl-Induced HighTemperature Corrosion of Alloy 310, J. Electrochem. Soc. 154 (2007) C515. 
[58] L.W. Sengeløv, T.B. Hansen, C. Bartolome, H. Wu, K.H. Pedersen, F.J. Frandsen, A.D. Jensen, P. Glarborg, Sulfation of Condensed Potassium Chloride by SO 2, Energy \& Fuels. 27 (2013) 3283-3289.

[59] K. Iisa, Y. Lu, K. Salmenoja, Sulfation of Potassium Chloride at Combustion Conditions, Energy \& Fuels. 13 (1999) 1184-1190.

[60] P. Glarborg, P. Marshall, Mechanism and modeling of the formation of gaseous alkali sulfates, Combust. Flame. 141 (2005) 22-39.

[61] M. Henriksson, B. Warnqvist, Kinetics of Formation of HCI(g) by the Reaction between NaCl(s) and SO2, 02, and H,O(g), Ind. Eng. Chem. Process Des. Dev. 18 (1979) 249-254.

[62] L. Boonsongsup, K. Iisa, W.J. Frederick, Kinetics of the Sulfation of $\mathrm{NaCl}$ at Combustion Conditions, Ind. Eng. Chem. Res. 5885 (1997) 4212-4216.

[63] A.B. Anderson, Mechanism for forming hydrogen chloride and sodium sulfate from sulfur trioxide, water, and sodium chloride, J. Am. Chem. Soc. 106 (1984) 6262-6265.

[64] J.P. Abellán, T. Olszewski, G.H. Meier, L. Singheiser, W.J. Quadakkers, The oxidation behaviour of the $9 \%$ Cr steel P92in CO 2 - and $\mathrm{H} 2$ O-rich gases relevant to oxyfuel environments, Int. J. Mater. Res. 101 (2010) 287-299. 


\section{Supporting Information}

Table S1. Elemental composition of selected locations of the corrosion product in Figure 4

\begin{tabular}{ccccc}
\hline \multirow{2}{*}{ Location } & \multicolumn{4}{c}{ elemental composition ${ }^{*}$ (wt \%) } \\
& O & S & Cl & K \\
1 & 37.3 & 18.9 & - & 43.8 \\
2 & 18.9 & 6.8 & 29.7 & 44.1
\end{tabular}

*due to the morphology of the measured locations, values < $1 \mathrm{wt} \%$ (denoted by '-') are not presented. The same holds for the subsequent tables.

Table S2. Elemental composition of selected locations of the corrosion product shown in Figure 5

\begin{tabular}{llllllll}
\hline \multirow{2}{*}{ location } & \multicolumn{7}{c}{ elemental composition (wt \%) } \\
& $\mathrm{O}$ & $\mathrm{S}$ & $\mathrm{Cl}$ & $\mathrm{K}$ & $\mathrm{Cr}$ & $\mathrm{Mn}$ & $\mathrm{Fe}$ \\
1 & 22.2 & 8.6 & 23.6 & 42.5 & - & - & 2.8 \\
2 & 33.8 & 16.0 & 2.5 & 39.0 & 1.1 & - & 7.6 \\
3 & 19.0 & 2.2 & - & 6.1 & 8.2 & 2.3 & 61.4 \\
\hline
\end{tabular}

Table S3. Elemental composition of selected locations of the corrosion product in Figure 6

\begin{tabular}{llcccc}
\hline \multirow{2}{*}{ location } & \multicolumn{5}{c}{ elemental composition (wt \%) } \\
& $\mathrm{O}$ & $\mathrm{Cr}$ & $\mathrm{Mn}$ & $\mathrm{Fe}$ & $\mathrm{Ni}$ \\
1 & 25.4 & 4.3 & 1.7 & 67.4 & - \\
2 & 27.1 & 38.3 & 2.1 & 25.3 & 4.7 \\
\hline
\end{tabular}

Table S4. Elemental composition of internally attacked regions shown in Figure 7

\begin{tabular}{llllll}
\hline location & \multicolumn{5}{c}{ elemental composition (wt \%) } \\
& $\mathrm{O}$ & $\mathrm{Cl}$ & $\mathrm{Cr}$ & $\mathrm{Fe}$ & $\mathrm{Ni}$ \\
1 & 19.2 & 1.8 & 22.9 & 30.2 & 22.7 \\
\hline
\end{tabular}

Table S5. Elemental composition of selected areas in Figure 16

\begin{tabular}{llllll}
\hline \multirow{2}{*}{ location } & \multicolumn{5}{c}{ elemental composition (wt \%) } \\
& $\mathrm{O}$ & $\mathrm{Cr}$ & $\mathrm{Mn}$ & $\mathrm{Fe}$ & $\mathrm{Ni}$ \\
1 & 32.1 & 4.2 & 1.6 & 61.1 & - \\
2 & 15.3 & 16.3 & 1.7 & 56.8 & 8.7 \\
\hline
\end{tabular}




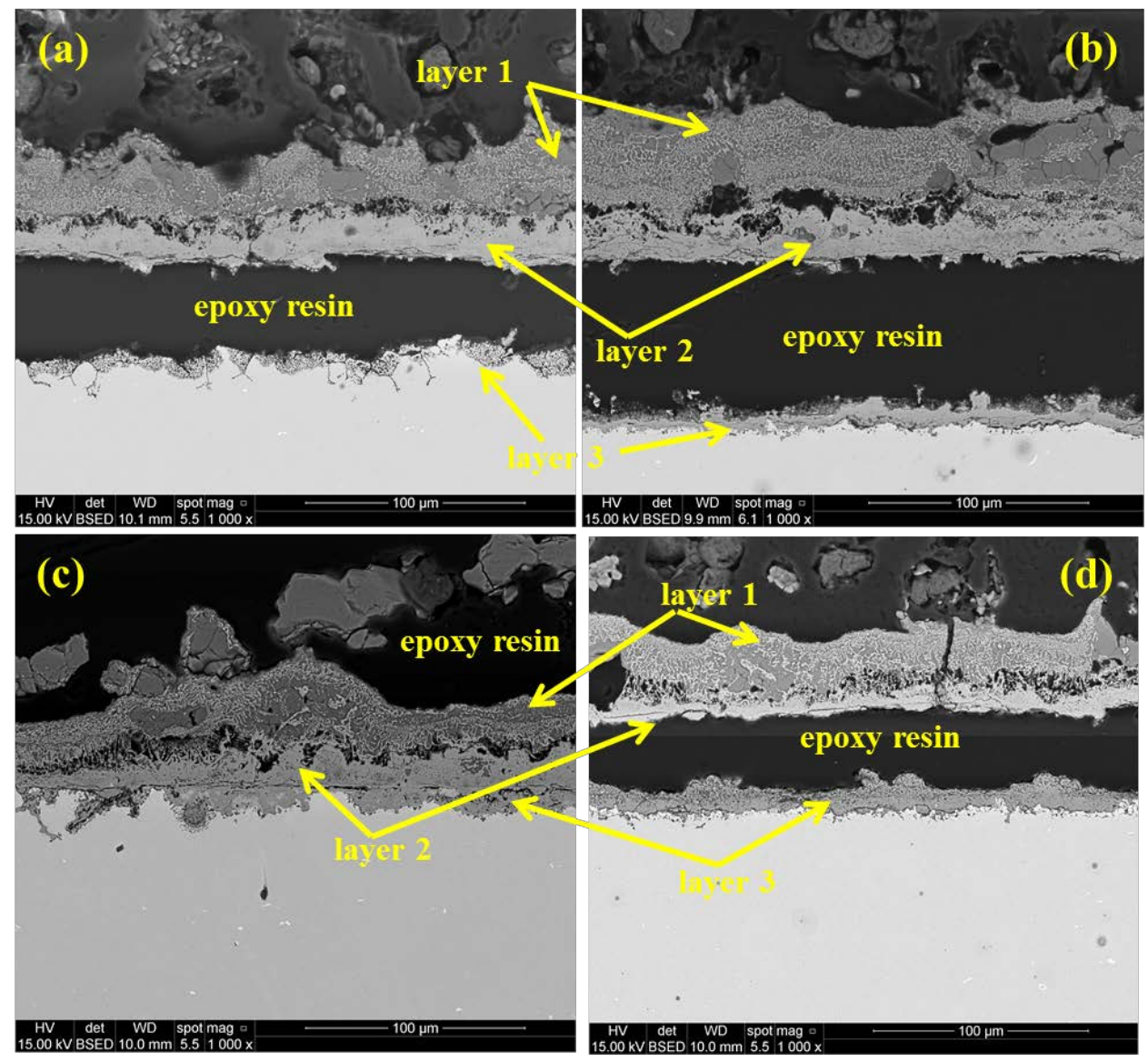

Figure S1. Selected BSE micrographs showing cross sections of corrosion products after exposure to the reference condition (straw-firing with 3 vol $\% \mathrm{H}_{2} \mathrm{O}, 168 \mathrm{~h}$ ) ${ }^{\text {a }}$.

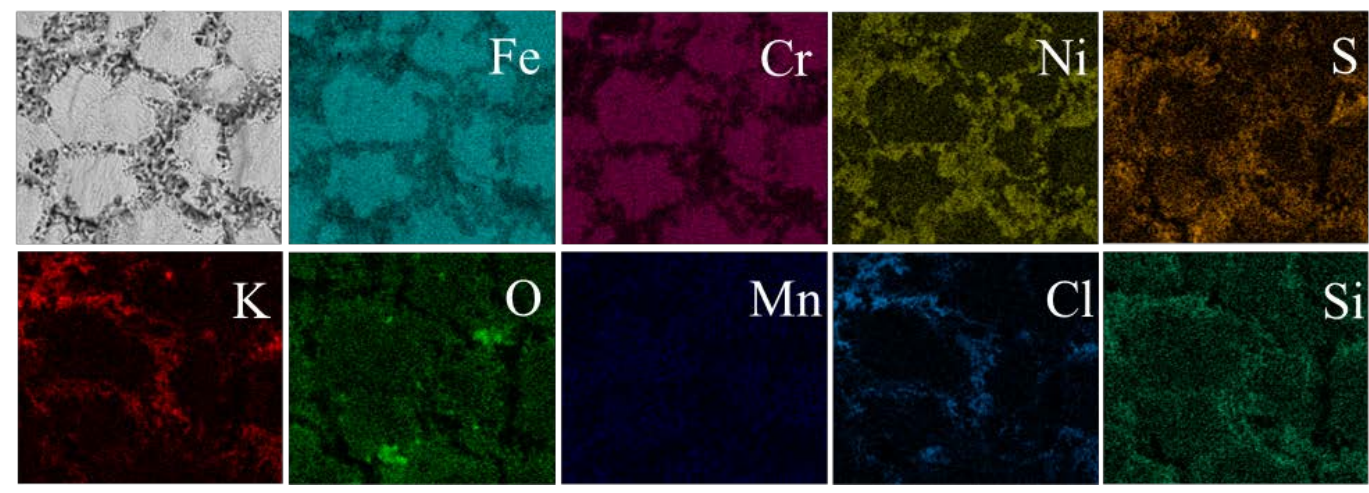

Figure S2. EDS elemental maps showing the elemental composition of the selectively attacked regions shown in Figure 14(c).

\section{Reference}

${ }^{a}$ Okoro, S. C.; Montgomery, M.; Frandsen, F. J.; Pantleon, K. Energy \& Fuels 2014, 28, 6447-6458. 